\title{
Active compressional tectonics, Quaternary capable faults, and the seismic landscape of the Po Plain (northern Italy)
}

\author{
Alessandro M. Michetti ${ }^{1,}{ }^{\star}$, Francesca Giardina ${ }^{1}$, Franz Livio $^{1}$, Karl Mueller ${ }^{2}$, Leonello Serva ${ }^{3}$, \\ Giancanio Sileo ${ }^{1}$, Eutizio Vittori ${ }^{3}$, Roberto Devoti ${ }^{4}$, Federica Riguzzi $^{4}$, Cipriano Carcano ${ }^{5}$, \\ Sergio Rogledi ${ }^{6}$, Livio Bonadeo ${ }^{1}$, Fabio Brunamonte ${ }^{1}$, Gianfranco Fioraso ${ }^{7}$
}

\author{
${ }^{1}$ Università dell'Insubria, Dipartimento di Scienza e Alta Tecnologia, Como, Italy \\ ${ }^{2}$ University of Colorado, Department of Geological Sciences, Boulder, CO, USA \\ ${ }^{3}$ ISPRA, Dipartimento Difesa del Suolo/Servizio Geologico d'Italia, Rome, Italy \\ ${ }^{4}$ Istituto Nazionale di Geofisica e Vulcanologia, Centro Nazionale Terremoti, Rome, Italy \\ ${ }^{5}$ Burren Resources Petroleum Ltd, Baza Burren, Burun Field, Balkanabat, Turkmenistan \\ ${ }^{6}$ ENI Exploration and Production, San Donato Milanese (Milan), Italy \\ ${ }^{7}$ Istituto di Geoscienze e Georisorse, Consiglio Nazionale delle Ricerche (CNR), Turin, Italy
}

\section{Article history}

Received November 2, 2011; accepted June 4, 2012.

Subject classification:

Active compressional tectonics, Paleoseismology, Seismic hazard, Po Plain foredeep, Seismic landscape, May 20, 2012, Emilia earthquake.

\section{ABSTRACT}

It is commonly believed that the Po Plain is an area of low seismic hazard. This conclusion is essentially a combination of two factors: (1) the historical record of earthquakes, which shows a relatively small number of events of moderate magnitude, and only two significant earthquakes, which occurred in the Middle Ages; and (2) the lack of ad-hoc research on the geology of earthquakes in this area, as although many studies have highlighted the local Quaternary tectonics, only a very few of them have discussed the observed evidence in terms of seismic hazard. In contrast, the data presented in the present study strongly suggest that the level of earthquake hazard in the Po Plain is comparable to that of the wellknown seismic areas of the Apennine range, at least in terms of maximum magnitudes. Indeed, the high population density and the concentration of industrial facilities make the Po Plain today one of the more high-risk areas of the Italian territory. The Po Plain represents the foredeep of two growing mountain belts, the southern Alps and the northern Apennines. Recently, modern active tectonics studies have been conducted along its margins to the south, along the northern Apennine Piedmont belt, and to the northeast, along the eastern southern Alpine Piedmont belt. However, in the central and western sectors of the Po Plain, where the south-verging western southern Alpine front links up with the north-verging Monferrato, Emilia and Ferrara arcs, the Quaternary history of tectonic deformation and faulting are still relatively poorly understood. These lie beneath the relatively flat alluvial surface of the Po River, and provide the evidence for paleoseismicity and the resulting seismic hazard. In this review, we compile the data from the literature to reassess the style and magnitude of the ongoing crustal deformation and the associated earthquake faulting. This includes detailed informa- tion on historical and instrumental seismicity, extensive subsurface information from the ENI industrial exploration, structural interpretation of three regional seismic reflection profiles, analysis of novel global positioning system data, field mapping at selected key areas, and new paleoseismological investigations. We show that along the western southern Alpine belt between Lake Garda and Lake Maggiore, the active tectonic setting is characterized by a segmented belt of fault-propagation folds. These are $50 \mathrm{~km}$ wide, and are controlled by the growth of out-of-sequence, 10-to-20-km-long, north and south verging thrusts. Regional global positioning system data show ongoing shortening rates of the order of $1 \mathrm{~mm} / \mathrm{yr}$. Quaternary fault slip rates typically range between $0.2 \mathrm{~mm} / \mathrm{yr}$ and $0.4 \mathrm{~mm} / \mathrm{yr}$. Pleistocene shortening is obvious not only along the western southern Alpine outer fronts that are buried beneath the Po Plain, but also along the south Alpine foothills between Brescia and Varese. Similar styles and rates of active folding and thrusting have also been documented along the frontal sector of the northern Apennine arcs, from Torino to Ferrara, and along the base of the Apennine mountain front between Piacenza and Bologna. We selected the Brescia and Como sectors in the western southern Alps and the Monferrato and Mirandola structures in the northern Apennines as examples to illustrate the seismic landscape of the study area, in terms of typical active structural, geomorphic and paleoseismic features. We argue that the level of earthquake hazard in the Po Plain is comparable to that of the Apennine range. On May 20, 2012, a few days after this review was formally accepted for publication, a $M_{W} 5.9$ earthquake ruptured the Mirandola structure. The seismic sequence following this mainshock is ongoing, and we have added further information about this event (updated on June 3rd, 2012), which substantially confirms the conclusions arrived at here. 


\section{Introduction}

Seismic hazard assessment worldwide is still essentially controlled by seismological data, which at the very best cover a time window of 2 or 3 millennia, with various degrees of completeness. However, relevant seismic events in the past decade have clearly illustrated the flaws of this approach. For instance, the devastating seismic sequences that hit New Zealand and Japan in 2010 and 2011 were regarded as surprises in terms of their dimensions and/or locations, and in both cases, this was mostly due to the lack of complete geological and paleoseismological investigations in the epicentral areas. In Japan, paleotsunami analyses [Sawai et al. 2007, Satake et al. 2008] have already indicated that the segmentation model adopted for the offshore Tohoku region in the Japanese National Seismic Hazard modeling [HERP 2009] might not have been appropriate. In the Christchurch region, the Darfield, September 4, 2010, $\mathrm{M}_{\mathrm{W}}$ 7.1, strike-slip surfacefaulting event [Barrel et al. 2011] reactivated a capable tectonic structure that was not recognized before, due to the lack of both high-resolution seismic reflection profiles and detailed investigations on paleoliquefaction in the Canterbury Plains.

Indeed, these events have emphasized once more that, "the most important contribution to the understanding of long-term seismicity, which is critical to the siting and design of safe structures and to the establishment of realistic building codes, is to learn more - region by region - of the late Quaternary history of deformation", which of course includes evidence for paleoseismicity. This is a quote from Allen [1975], a study that partly inspired the topic of the present review. A retrospective look at the origin of the science of paleoseismology is surprisingly instructive today, while we are still shocked by the effects of the 2011 'catastrophic' seismic crises.

The objective of the present review is to argue that the approach discussed by Allen [1975] and further developed by Serva [1996] and Michetti et al. [2005a], among others, is definitely validated by the observations conducted before and after the 2011 large earthquakes. These studies introduced the concept of seismic landscape, and this validation is true not only for countries that are seismically very active, such as New Zealand and Japan. Four decades of seismotectonic studies in the Po Plain teach us the same lesson. This is a region that is characterized by moderate historical seismicity, and it is one of the most populated and developed areas of Europe. The Po Plain also hosts a substantial portion of Italian industrial production, with many critical infrastructures and a number of industrial plants that pose high environmental risk.

The Po Plain is the foredeep basin in northern Italy where the Alps-Apennines junction is located (Figure 1). Very detailed geological maps, subsurface data, and an excellent historical database are available for this region, and include a very long and high-quality seismic catalog. Efforts to use these data to understand the neotectonic history and related seismic hazards were undertaken about 30 years ago, during the investigations of the Italian program for nuclear power-plant siting [e.g., ENEL-DCO 1984, Serva 1990, and references therein], and the related Progetto Finalizzato Geodinamica of the CNR (Italian National Research Council) [e.g., Bigi et al. 1990]. The seismotectonic knowledge that was gathered in that period provided the conceptual framework for the first application of paleoseismic analyses in Italy. Since then, however, while the active tectonics of the eastern southern Alps (ESA) [e.g., Benedetti et al. 2000, Galadini et al. 2005, Burrato et al. 2008, Poli et al. 2008] and the Apennine margin of the Po Plain have been carefully reconsidered [e.g., Benedetti et al. 2003, Boccaletti and Martelli 2004, Scrocca et al. 2007, Toscani et al. 2009, Boccaletti et al. 2011], no systematic detailed studies have been performed in the region west of Lake Garda.

Neither the southern Alps nor the northern Apennines are characterized by high seismicity and highly active tectonic structures, especially if compared with other active mountain belts around the world [for a comprehensive review, see Dolan and Avouac 2007]. Shortening rates in this sector of the Adriatic foredeep have clearly decreased from some $\mathrm{cm} / \mathrm{yr}$ during the Oligo-Miocene to some $\mathrm{mm} / \mathrm{yr}$ during the Pleistocene [e.g., Castellarin et al. 2006, Scrocca et al. 2007, Boccaletti et al. 2011].

The structural evolution of the Po Plain foredeep has been interpreted in some studies as recording the late Neogene deactivation of both the western southern Alps (WSA) [e.g., Fantoni et al. 2004, Scardia et al. 2006, and references therein] and the northern Apennines [e.g., Bertotti et al. 1997, Di Bucci and Mazzoli 2002, Argnani et al. 2003, and references therein]. As a result, and also taking into account the infrequent seismic events in the local catalog [e.g. Postpischl 1985, Boschi et al. 2000, CPTI Workgroup 2004, Guidoboni et al. 2007], this area is generally considered as one of the least seismically hazardous regions of the whole Italian peninsula [Albarello et al. 2000, Stucchi 2004]. In the last seismic source zone model that was adopted for the national probabilistic seismic-hazard assessment [Meletti et al. 2008], the Bergamo and Brescia area was included in a low seismicity zone, which is regarded as the westward termination of the ESA seismogenic belt. Surprisingly enough, the Milan, Como and Varese provinces and the Monferrato arc are included in a "zone of low diffuse seismicity". Along the same lines, the compilation of significant $\left(\mathrm{M}_{\mathrm{W}}>5.5\right)$ earthquake sources by Basili et al. [2008] did not consider any seismogenic sources or areas for these provinces. In contrast, the seismic hazard in the ESA is considered to be relatively high [e.g., Burrato et al. 2008].

We argue here that this contrast might largely be an artifact, due to: (A) the inherent inadequacy of the historical 


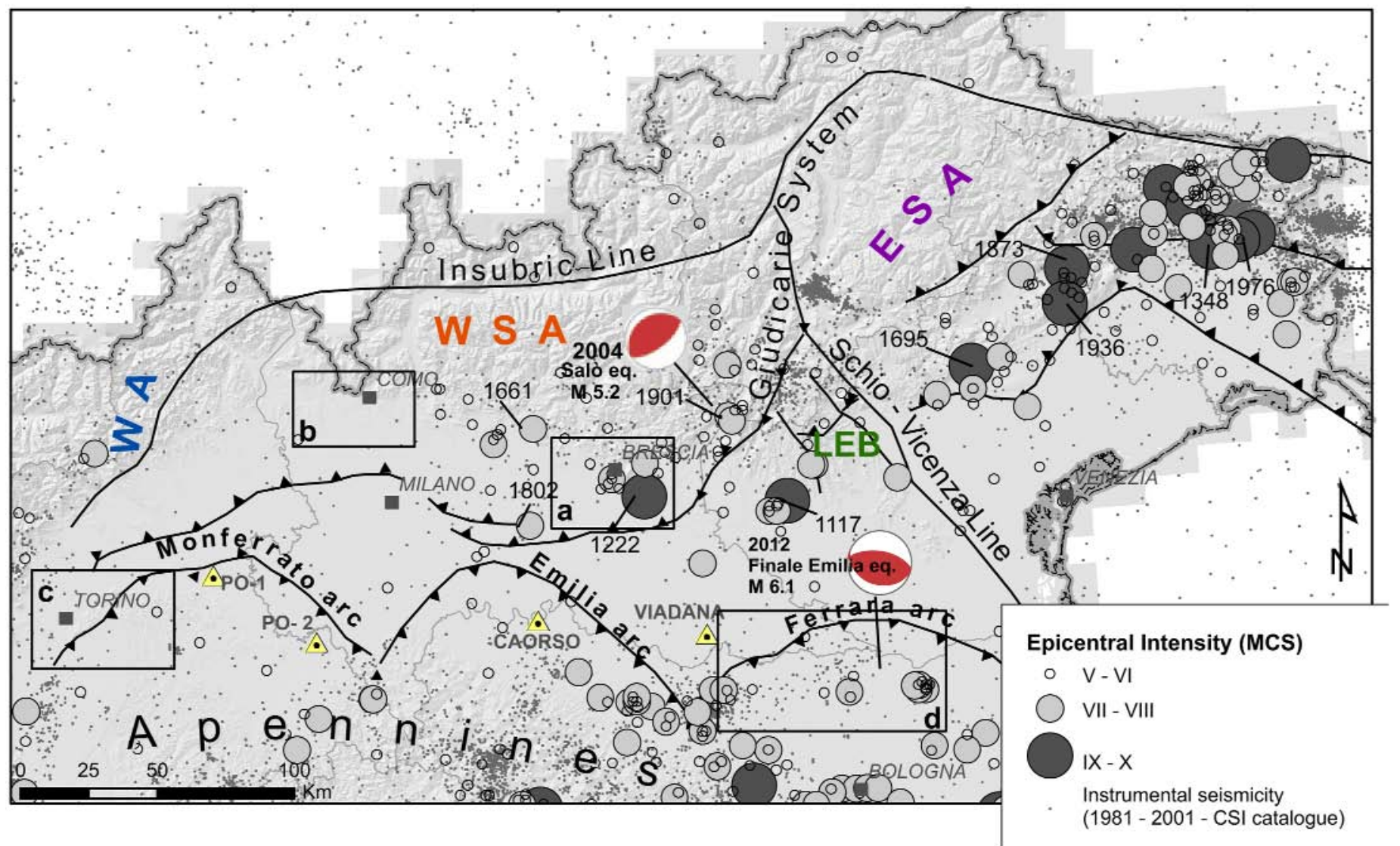

Figure 1. Seismotectonic map of northern Italy. Main tectonic lineaments modified from Castellarin et al. [2006] and Scrocca et al. [2007]. Seismicity from CPTI Workgroup [2004], except for: the 1222 Brescia event, which is relocated based on Guidoboni and Comastri [2005]; the November 24, 2004, Salò earthquake epicentral location, magnitude and focal mechanism [INGV 2004]; and the May 20, 2012, Finale Emilia earthquake epicentral location, focal mechanism [INGV 2012] and magnitude (Mw 6.1, USGS 2012; Mw 5.9) [INGV 2012]. Yellow triangles show the areas selected 20 years ago for nuclear power plant siting; boxes locate the case studies described in this review. WSA, western southern Alps; ESA, eastern southern Alps; WA, western Alps; LEB, Lessini-Euganei-Berici hills.

catalog (even if is very long and of high quality, like the one that is available in Italy) to correctly depict the level of seismicity in such a moderately active region; and (B) the lack of detailed and specific geological studies on the Quaternary tectonics and paleoseismicity of the Po Plain. Following an alternative seismotectonic scenario, geomorphological analyses, subsurface geology, seismicity and present day stress fields have been interpreted as suggesting that tectonic activity of the frontal part of the WSA and the Apennine arc is still going on [e.g., Serva 1990, Giglia et al. 1996, Burrato et al. 2003, Boccaletti et al. 2004, Scrocca et al. 2007, Sileo et al. 2007, Livio et al. 2009a, Livio et al. 2009b, Toscani et al. 2009, and references therein]. This implies that in terms of the maximum credible magnitude for the reference earthquake, the seismic hazard of the Po Plain might be seriously underestimated.

Our review is therefore aimed at: (1) assessing the style and magnitude of the recent and ongoing crustal deformation; (2) inferring the seismotectonic potential for this region; and, finally, (3) depicting the seismic landscape [Michetti et al. 2005a] for the Po Plain foredeep. To this end, as indicators of the present-day strain in different sectors of the whole plain, we have here compiled and combined: (a) subsurface oil exploration data over a large sector of the study area; (b) pub- lished and novel stratigraphic, geomorphic and geodetic evidence of recent and ongoing shortening; and (c) preliminary paleoseismological analyses at selected sites.

We focus on four case studies: two along the WSA, i.e., the Brescia area and the Insubria region (western Lombardy and Ticino), which are treated in more detail due to the availability of new fieldwork and paleoseismic analyses; and two along the northern Apennines, i.e., the Torino hill-Monferrato area and the Mirandola structure in the Ferrara arc, where our analysis is mostly based on published information. These case studies show confirmatory evidence of Quaternary compressional tectonics, and sometimes of paleoseismicity. At all of the selected locations, ENI E\&P seismic profiles of excellent quality provide detailed information on the deep structural setting.

Although suitable characterizations of each Quaternary capable fault and fold [sensu Michetti et al. 2005a] in Lombardia, Emilia, Piemonte and Ticino are still in their infancy, the results described in the following allow an entire reconsideration of the evidence of Quaternary shortening and the associated local seismic potential. More in general, these allow concern to be raised for better use of the geological data for earthquake hazard assessment in areas of moderate seismicity. 
On May 20, 2012, a few days after this review was formally accepted for publication, a $\mathrm{M}_{\mathrm{W}} 5.9$ [INGV 2012] earthquake ruptured the Mirandola structure, which was one of the case studies we had selected for this review. This event is arguably the largest earthquake recorded in the Po Plain since seismic events of the Middle Ages that occurred near Verona and Brescia, in 1117 A.D. and 1222 A.D., respectively. The seismic sequence that followed the May 20, 2012, mainshock is ongoing, and we have since added some information about this event (as updated on June 3rd, 2012), which substantially confirms the conclusions that we arrived at below.

\section{Tectonic and seismological framework of the Po Plain}

The study area is the central and western sector of the Po Plain, which is a predominantly flat fluvial basin that is elongated in an east-west direction between the mountain ranges of the Alps and the Apennines. This area is bounded to the northeast by the Lessini-Euganei-Berici hills (Figure 1, LEB), which separate this sector from the Veneto and Friuli plains. Towards the western geographic termination, the Po Plain is dominated by the Torino and Monferrato hills, which bound and separate the different alluvial sub-basins.

The Po Plain foredeep is characterized by the convergence of two chains that face each other beneath the Po River floodplain: the WSA and the northern Apennines [e.g., Castellarin et al. 1985, Castellarin and Vai 1986, Castellarin et al. 1992, Doglioni 1993, Giglia et al. 1996, Castellarin and Cantelli 2000, Fantoni et al. 2004, Carminati et al. 2004, Mosca et al. 2009] (Figure 1). The WSA are related to the subduction of Europe underneath the Adriatic plate, whereas the northern Apennines are generated along the 'westward' subduction of the Adriatic lithosphere below the Tyrrhenian Basin.

The southern Alps are bounded to the north by the Insubric Line, and they are the conjugate retro-wedge of the Alps. They were generated from the early stages of the subduction, and they mainly developed during the collision stages of the orogeny. In particular, the investigated area was incorporated into the southern Alps during the Oligocene to Tortonian tectonic phase [e.g., Castellarin et al. 2006]. In the WSA, thrusts mainly verge to the south, and these have geometries that are influenced and partly driven by the architecture of the inherited Mesozoic passive continental margin [e.g., Assereto and Casati 1965, Winterer and Bosellini 1981, Gaetani and Jadoul 1987, Bernoulli et al. 1990, Doglioni 1992, Bertotti et al. 1993, Castellarin et al. 2004, Ravaglia et al. 2006]. During the Mesozoic rifting stage, this sector was characterized by north-south trending, listric normal faults that controlled the transition between the thick successions of carbonatic platforms and the contemporary basinal sediments. Afterwards, during the Alpine orogeny, these extensional structures underwent reactivation, with local tectonic inversion. During the Mesozoic, one of these important inherited structures, the Ballino-Garda Line, which lies along the Giudicarie System (Figure 1), marked the border between the Lombardian Basin to the west and the Trento Platform to the east [e.g., Castellarin and Sartori 1983]. This has successively acted as a rheological boundary since the early phases of the Alpine orogenesis, which occurred in the late Cretaceous [e.g., Doglioni and Bosellini 1987]. Following the indentation of the Adriatic lithosphere against the northern Alpine orogenic wedge, the southern Alps developed as a Neogene, south-vergent, fold-and-thrust belt, which is composed of two different tectonic domains: the ESA and the WSA [e.g., Castellarin et al. 2004]. These two sectors have independent foredeeps that are filled with a thick succession of mainly Tertiary units (the Gonfolite Lombarda Group, for the WSA foredeep) and are separated by the Lessini-Euganei-Berici structural high [e.g., Castellarin et al. 2006].

The structural front of the northern Apennines is not coincident with the topographic mountain front, but runs over $50 \mathrm{~km}$ to the north, buried below the Plio-Pleistocene infilling of the Po Basin. Three main salients can be identified, from west to east: the Monferrato, the Emilia and the Ferrara arcs (Figure 1). As for the southern Alps, the geometry of these structures is clearly controlled by the architecture of the deformed Mesozoic continental margin. The last major phase of thrust growth along the Apennine arcs in the Po Plain foredeep occurred between the Pliocene and the early Pleistocene [e.g., Castellarin et al. 1985, Bally et al. 1986, Ori et al. 1986], in reply to the retreat of the subducting Adria lithospheric plate. Different views co-exist regarding the late Quaternary and present-day activity of this province. According to some studies [e.g., Argnani et al. 1997, Bertotti et al. 1997, Di Bucci and Mazzoli 2002, Argnani et al. 2003, and reference therein], following a major geodynamic change at the Early to Mid-Pleistocene transition, the thrusting and related folding at the front of the Apennines ceased both in the Po Plain and in the adjacent sector of the Adriatic Sea. This is supported by both field mapping and interpretations of seismic reflection lines, which reportedly show thrusts sealed by almost undeformed Mid-Pleistocene to Holocene alluvial deposits [e.g., Picotti and Pazzaglia 2008].

Conversely, according to others [including, for instance, Serva 1990, Giglia et al. 1996, Selvaggi et al. 2001, Burrato et al. 2003, Boccaletti et al. 2004, Toscani et al. 2006, Scrocca et al. 2007, Meletti et al. 2008, Boccaletti et al. 2011, and references therein], macroseismic information on historical earthquakes, seismological data, geomorphic features, subsurface geology, and present-day stress fields demonstrate that the frontal part of the northern Apennines accretionary wedge is characterized by active shallow crustal shortening. The Apennine mountain front and the adjacent Piedmont belt in Emilia along the southern edge of the Po Plain show clear evidence of tilted and offset late Quaternary deposits [e.g., Amorosi et al. 1996, Boccaletti et al. 2011]. This is related to the activity of a regional thrust, the so-called Pede-Apenninic 


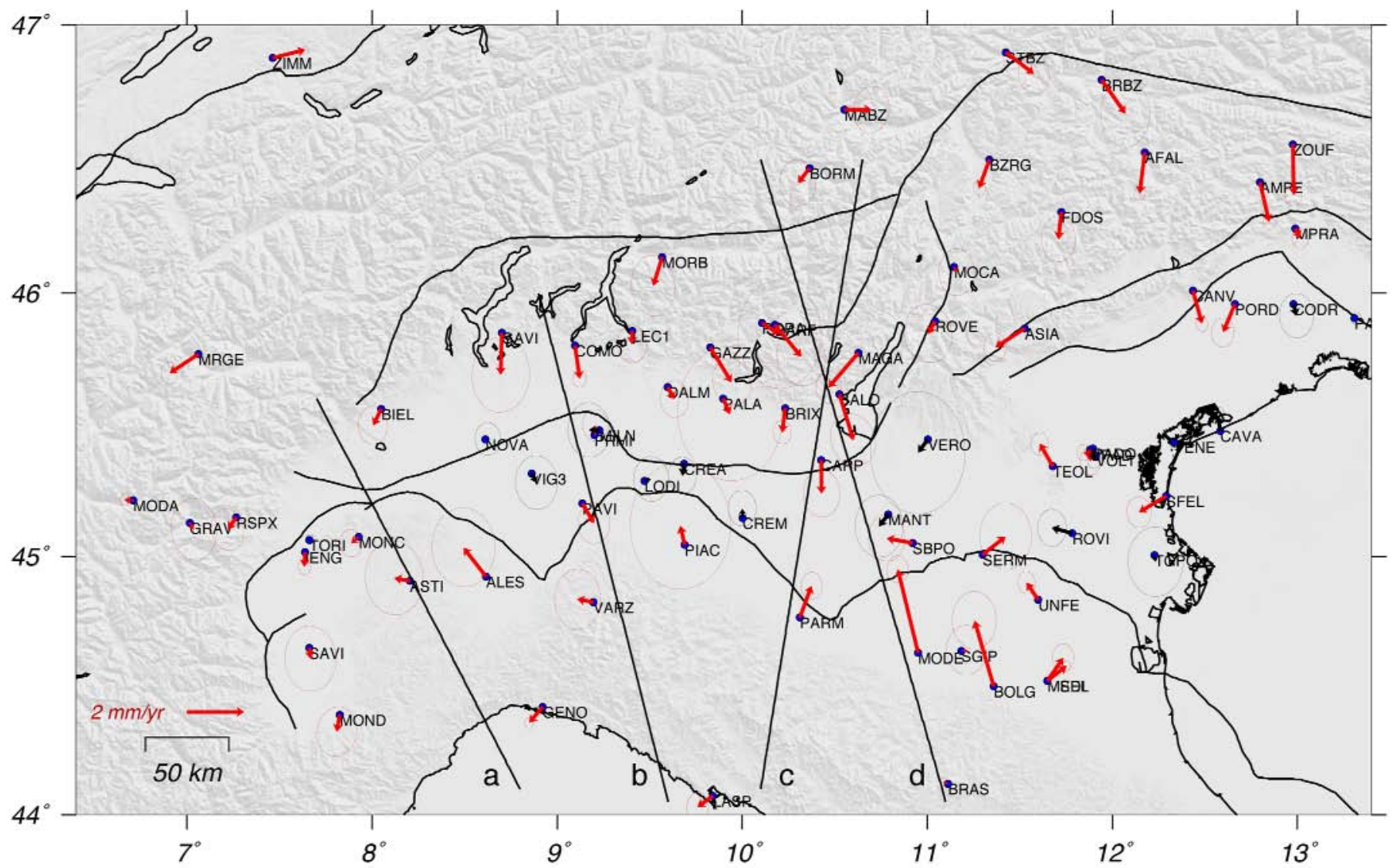

Figure 2. Horizontal velocity field in northern Italy, expressed with respect to a nonmoving Adriatic microplate defined by sites located in the Po Plain (black arrows). Velocity ellipses represent 1-sigma confidence error regions. Lines show the traces of the velocity profiles reported in Figure 3.

Thrust Front [e.g., Boccaletti et al. 1985, Castellarin et al. 1985, Amorosi et al. 1996, Benedetti et al. 2003, Boccaletti et al. 2011]. Quaternary growth of the fault propagation folds beneath the Monferrato and Torino hills has been shown, for instance, by the dramatic drainage changes that affected the Po, Dora Baltea and Tanaro Rivers in Piemonte [e.g. Forno 1982, Carraro et al. 1995].

In the area between the Pede-Apenninic Thrust and the external fronts of the Emilia and Ferrara arcs, and also across the Monferrato arc, an active compressional tectonic regime has been unequivocally documented by both borehole breakout data [e.g., Montone et al. 2004], which show a roughly north-south maximum horizontal stress, and focal mechanisms and other seismological data [e.g. Gasparini et al. 1985, Giglia et al. 1996, Frepoli and Amato 1997, Selvaggi et al. 2001, Eva et al. 2005, Boccaletti et al. 2011]. Furthermore, topographic leveling [e.g., Arca and Beretta 1985] and recent global positioning system (GPS) observations [e.g., Caporali et al. 2003, Battaglia et al. 2004, Serpelloni et al. 2005, Baldi et al. 2009, Devoti et al. 2011] have shown uplift and shortening of a few $\mathrm{mm} / \mathrm{yr}$ along and across the Apennine arcs. All of the described observations, as well as the results of geomorphological analyses, suggest the presence of active thrust fronts associated with growing fault-related folds [e.g., Desio 1965, Serva 1990, Carraro et al. 1995, Giglia et al. 1996, ITHACA 2000, Burrato et al. 2003, Benedetti et al. 2003,
Scrocca et al. 2007, Boccaletti et al. 2011]. The same conclusion arose from the interpretation of seismic reflection profiles, as discussed, for instance, by Boccaletti et al. [2004, 2011] and Mosca et al. [2009]. The active thrust-related folds are spatially arranged along seismogenic belts that are nearly coincident with the buried Monferrato, Emilia and FerraraRomagna arcs. The style of faulting and the GPS data during the seismic sequence initiated on May 20, 2012, demonstrates beyond doubt the ongoing tectonic shortening of the Po Plain foredeep.

It is important to note that long-term Quaternary shortening rates decrease westwards along the leading edge of the Apennine fold-and-thrust belt, from the Ferrara to the Emilia and Monferrato arcs (Figure 1) [e.g., Pieri and Groppi 1981, Bigi et al. 1990, Serva 1990, Doglioni 1993, Bartolini et al. 1996, Selvaggi et al. 2001, Bello and Fantoni 2002, Fantoni et al. 2004, Boccaletti and Martelli 2004, Scrocca et al. 2007]. This is consistent with a similar decrease from east to west that has been measured in the short-term geodetic strain rates [e.g., Battaglia et al. 2004, Serpelloni et al. 2005, Devoti et al. 2011]. Quaternary strain gradients and deformation rates are also mimicked by the regional temporal and spatial distributions of historical seismicity [CPTI Workgroup 2004, Guidoboni et al. 2007] (Figure 1), with moderate earthquakes (maximum epicentral intensity of VIII to IX on the MercalliCancani-Sieberg $[\mathrm{MCS}]$ scale, and observed magnitude in the 
range of $M_{W} 5.5$ to 5.8) more frequent in the east (Ferrara) than in the west (Monferrato) [e.g. Serva 1990, Giglia et al. 1996, Selvaggi et al. 2001, Boccaletti and Martelli 2004].

In the southern Alps, moving along the piedmont belt from east to west it is possible to observe a similar decrease in the Quaternary crustal shortening rates. Modern seismicity and geodetic strain rates also display the same trend, with higher seismicity levels and strain rates in the east [e.g., Serva 1990, Doglioni 1993, Castellarin and Cantelli 2000, D'Agostino et al. 2005, Castellarin et al. 2006, Poli et al. 2008]. Based on the available observations from the historical time window, earthquakes have higher maximum magnitudes (of the order of $M_{W} 6.5$ to 7) than in the northern Apennines, as illustrated by the seismicity in the areas of Friuli (e.g., the January 25, 1348. Carnia earthquake) [Slejko et al. 1987, Barbano 1993, Poli et al. 2008] and Lake Garda (e.g., the January 3, 1117, Verona earthquake, and the Christmas 1222, Brescia earthquake, with macroseismically derived magnitudes $\mathrm{M}_{\mathrm{E}}=7.1$ and 6.2, respectively) [Guidoboni 1986, Magri and Molin 1986, Serva 1990, Galadini et al. 2001a, Galadini et al. 2001b, Sauro and Zampieri 2001, Burrato et al. 2003, Guidoboni and Comastri 2005, Guidoboni et al. 2005, Peresan et al. 2009]. These strong historical seismic events show longer recurrence in the west, near Brescia and Verona, than in the Friuli area. This trend is consistent with the present-day increasing strain rates towards the east, as depicted by the available geodetic information. As already pointed out, instrumentally derived velocity fields indicate that the southern Alps Piedmont belt has actively shortened in the east at twice the rate compared to the west, as a consequence of the anticlockwise rotation of the Adriatic microplate around a pole located in the western Alps (some GPS estimates are reported in Weber et al. 2010).

The westwards decreasing of the crustal shortening in the southern Alps and Apennines does not, however, mean tectonic inactivity in the westernmost sectors of both of these chains. As mentioned above, Quaternary tectonic landforms, displaced Pleistocene deposits, and relevant seismic events have been described in the literature [Desio 1965, Carraro et al. 1995, Giglia et al. 1996, Zanchi et al. 1997, Burrato et al. 2003, Giardina et al. 2004, Sileo et al. 2007, Livio et al. 2009a, Livio et al. 2009b, Albini and Rovida 2010]. In particular, several damaging historical earthquakes occurred near Brescia (e.g., the above-mentioned Christmas 1222 event), Monza (November 26, 1396, I $=$ VII MCS) [Guidoboni and Comastri 2005], Lake Iseo (March 12, 1661, $\mathrm{I}_{\mathrm{O}}=$ VII MCS) and Valle dell'Oglio (near Soncino; May 12, 1802, $\mathrm{I}_{\mathrm{O}}=$ VIII MCS, $M_{E}$ 5.7). In more recent years, focal solutions of low magnitude seismicity [Viganò et al. 2008] also suggest that the WSA is characterized by active shortening. These include in particular the $M_{L} 5.2$, November 24, 2004, Salò event [Michetti et al. 2005b, Pessina et al. 2006] (see Figure 1 for location and focal mechanism), and the November 13, 2002, Lake Iseo event ( $M_{L}$ 4.2).

\section{GPS data}

Studies of seismic cycles and earthquake occurrence show how earthquakes have a higher probability to be generated along fault segments with the highest strain rate gradient, enucleating where the strain rate is lower [Doglioni et al. 2012, Riguzzi et al. 2012]. Currently, the strain rate is obtained from the spatial gradient of the GPS velocity field, as recently estimated for the Italian area. In our view, the GPS interseismic velocity field is driven by the dynamics of deep lithospheric structures that engage the whole lithosphere and are modulated by the interactions between the brittle lithosphere and deeper ductile layers along the brittle-ductile transition zone [Devoti et al. 2011, Doglioni et al. 2011]. Consequently, knowledge of the GPS velocities and gradients appears relevant for seismic hazard studies.

To better highlight the kinematics across the AlpineApennine fronts, the horizontal GPS velocity field in northern Italy is expressed with respect to a nonmoving Adriatic microplate that is defined by sites located in the Po Plain (Figure 2, black arrows). This represents a portion of the larger velocity solution of the Italian area that was provided by Devoti et al. [2011]. The velocity field was estimated by leastsquares inversion, taking into account only GPS sites with more than $2.5 \mathrm{yr}$ of coordinate determination. We selected four different profiles (Figures 2 and 3 ) that cross the fronts along which we projected the horizontal velocities located within a distance of $40 \mathrm{~km}$. The projections are computed from south to north, so that the northwards-oriented velocities are positive and the southwards-directed velocities are negative. This representation is useful to distinguish the sites belonging to the Apennine domain (positive velocity projections) from those of the Alpine domain (negative velocity projections). The transition area, which has null projected velocity, is represented by the sites located in the Po Plain outside the fronts.

From Figure 3, it is possible to draw the following considerations:

Profile (a): No significant velocity variations are detected across the fronts; the two sites south of the Apennine front have large uncertainty values.

Profile (b): Unfortunately, the GPS sites are not as dense as in other places, and large gaps in the network geometry restrain the possibility of having a clear kinematic picture of this area. Nevertheless, with respect to the Po Plain zero level (Figure 3, horizontal gray line), the two Apennine sites show low-level positive velocities (ca. $0.5 \mathrm{~mm} / \mathrm{yr}$ ), whereas the three Alpine sites show negative velocities (ca. $1 \mathrm{~mm} / \mathrm{yr}$ ). The low signal-to-noise ratio does not allow a clear kinematic picture. The total shortening component across the fronts is about $1.5 \mathrm{~mm} / \mathrm{yr}$.

Profile (c): Along this profile, the trend of the projected velocities assumes a clearer pattern, even if only one site is representative of the Apennine front domain. The total 

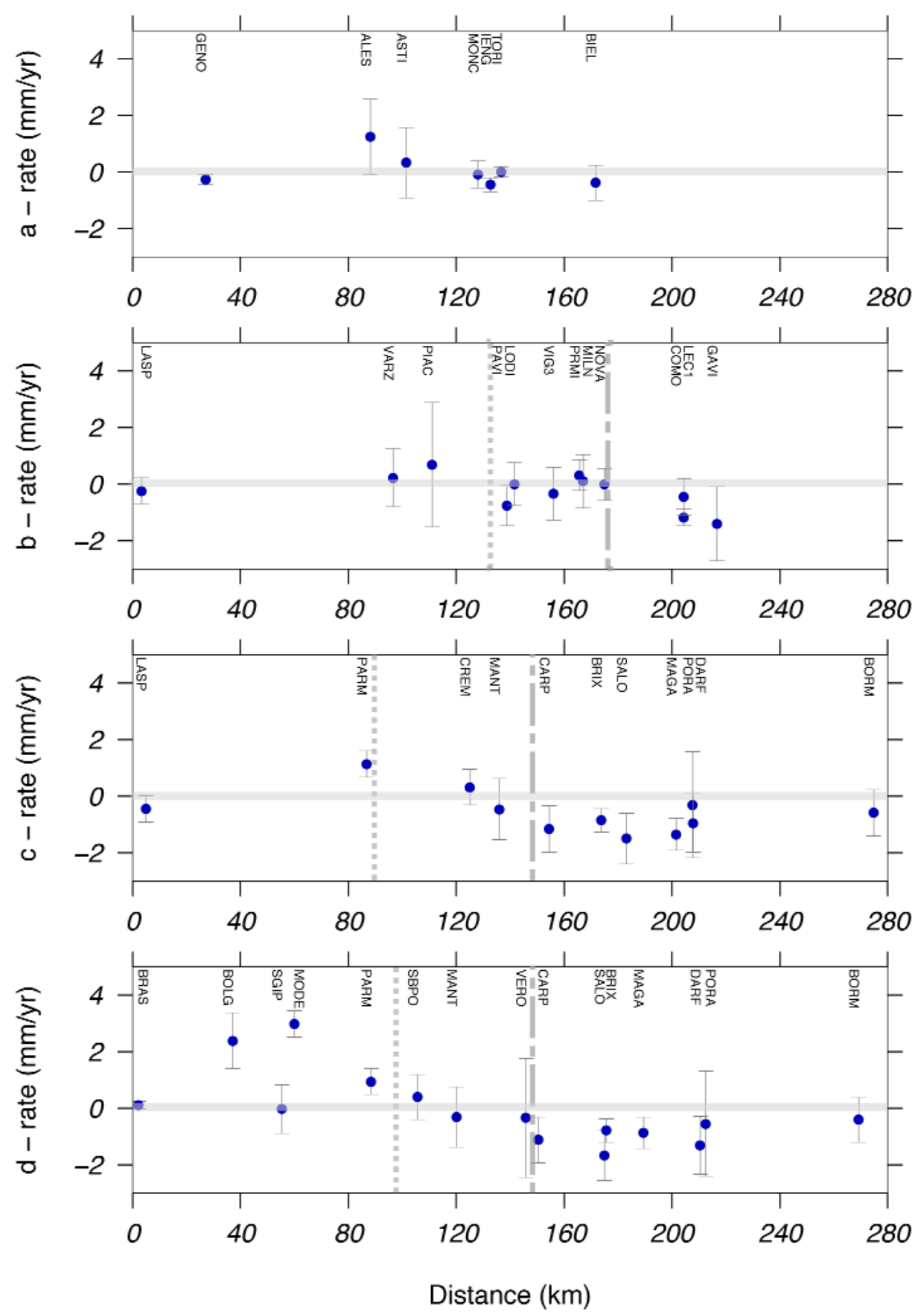

Figure 3. Horizontal velocity projections across the four profiles from Figure 2. Vertical gray dashed lines show the intersections with the fronts (small dashed, Apennines; large, Alps). The horizontal line identifies the Po Plain reference.

shortening component across the fronts is ca. $2 \mathrm{~mm} / \mathrm{yr}$.

Profile (d): This is the profile that shows more defined kinematics. The sites located near the Apennine front have the largest projected velocities, with greater shortening with respect to those of the Alpine front. The total shortening component across the fronts is about $2.5 \mathrm{~mm} / \mathrm{yr}$.

In conclusion, with respect to the Po Plain, the Alpine front shows a behavior that is spatially continuous from west to east (apart from the western-most sector), with more or less the same level of shortening (ca. $0.5 \mathrm{~mm} / \mathrm{yr}$ ). On the contrary, from west to east, the Apennine front shows increasing shortening, from ca. $0 \mathrm{~mm} / \mathrm{yr}$ to about $2 \mathrm{~mm} / \mathrm{yr}$.

\section{Case study 1: the eastern Lombardy-Brescia area}

To check on possible evidence of active shortening and faulting along the buried fronts of this sector of the WSA, we reinterpreted a large amount of ENI E\&P seismic reflection data, which covered an area of ca. $7000 \mathrm{~km}^{2}$ in the central part of the Po Plain (Figure 4a). We used ca. $18000 \mathrm{~km}$ of seismic lines, which were calibrated through about 100 

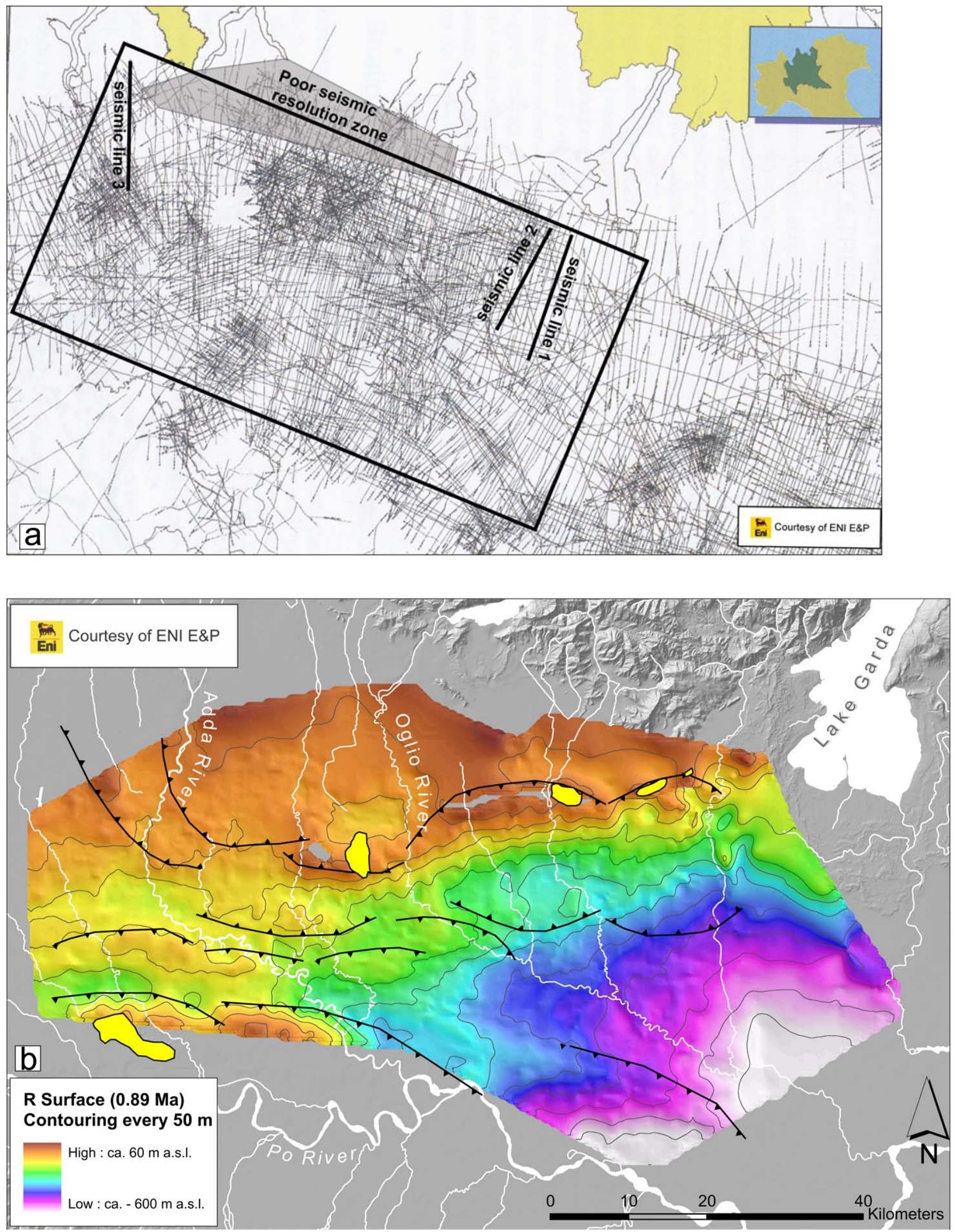

Figure 4. (a) Map of the seismic lines made available by ENI E\&P. Solid lines mark the approximate locations of the seismic profiles shown in Figures 7 and 12. The gray area indicates poor signal-to-noise ratio in the seismic reflection data, due to reverberation effects in the local coarse, strongly cemented fluvioglacial deposits ('Ceppo Formation') [e.g., Orombelli 1979]. (b) Map of the R-surface (a sequence boundary in the Po Basin subsurface, dated at ca. 0.89 Ma), redefined using the ENI E\&P data. Generally this surface deepens toward the southeast, but in some cases it rises up to the surface (yellow areas show the more uplifted and eroded parts), driven by the growth of buried thrusts. Therefore, from the R-surface shape it is possible to evaluate the distribution and geometries of active tectonic structures in the northern Po Plain. The projection on the surface of the buried thrust tip lines is also shown. 


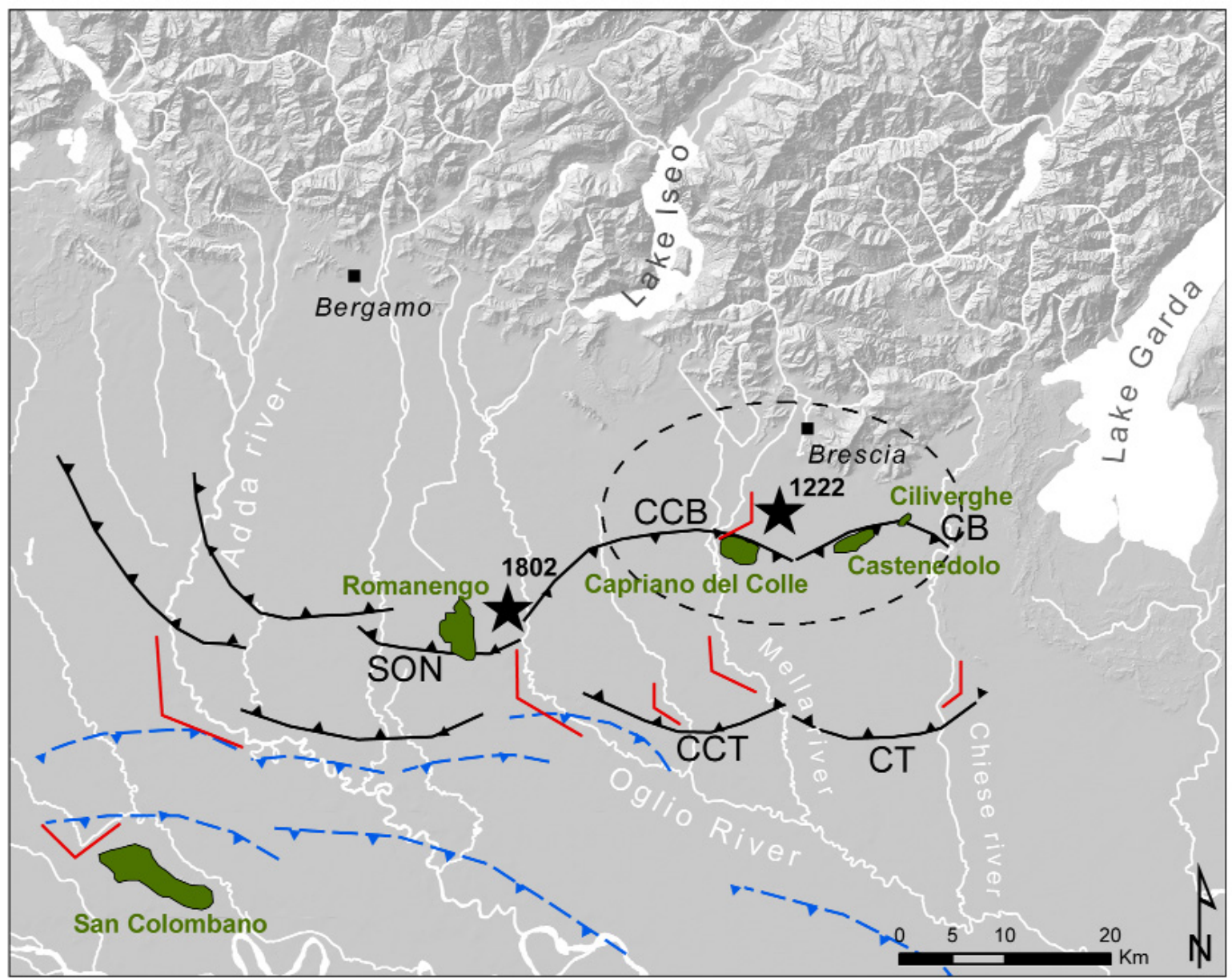

Figure 5. Quaternary buried capable faults along the western southern Alps (WSA) Piedmont belt. The lack of Quaternary structures southwest of Lake Iseo is due to a lack of information, and work is in progress to interpret the fault geometries and the activity in that area. Alpine structures are in black, and Apennine structures in blue. The isolated hills encircled by the plain are highlighted in green, The deviations of some main of the rivers, which appear driven by tectonic activity [e.g., Burrato et al. 2003] are indicated in red. Stars indicate earthquake epicentral locations. CCB, Capriano del Colle backthrust; CB, Capriano del Colle thrust; CCT, Castenedolo backthrust; CT, Castenedolo thrust; SON, Soncino thrust.

deep industrial boreholes. Two horizons were mapped on selected seismic lines: (a) the Aptian unconformity (the upper part of the Maiolica Fm.) [e.g., Bersezio et al. 2002]; and (b) the base of the early Oligocene (the base of the 'Gonfolite Lombarda' Group) [e.g. Sciunnach and Tremolada 2004]. The main detachments are usually located along these horizons, due to the presence of rheologically weak layers. These data were used to constrain a first interpretation and to depict the structural style that characterizes adjacent sectors of the buried chain. We then revised and contoured four regional marker horizons of known age, which included from the base: (1) the base of the Pliocene; (2) a surface dated at ca. the base of the Calabrian (Blue surface - 1.6 Ma); (3) a surface dated at ca. 1.2 Ma; and (4) the R-surface, a sequence boundary dated at ca. $0.89 \mathrm{Ma}$ (Figure 4b) [see details in Carcano and Piccin 2002, Muttoni et al. 2003]. Our study focuses on the analysis of the shallowest portions of the readable seismic lines, the re-interpretation of the base of the slope-basin transition, and the integration with several water-well stratigraphic logs.

The Blue and R-surface have been analyzed to reveal localized deformations that were induced by the Quaternary activity of buried structures (Figures $4 \mathrm{~b}$ and 5). We identified a belt of segmented fault-propagation folds that are 10 to $20 \mathrm{~km}$ long and show evidence of Quaternary activity; these sit above south-verging and north-verging, out-of-sequence thrusts (Figures 5 and 6). The controlling structures developed mostly during the Oligo-Miocene Alpine tectonic phase, and continued to grow later, as demonstrated by the subtle deformations induced in the Plio-Quaternary syngrowth sequence (Figure 7) [Burrato et al. 2003, Giardina 2006, Livio et al. 2009a, Livio et al. 2009b].

The Castenedolo backthrust (Figures 5 and 6, CB) is part of a triangle zone or wedge thrust [e.g. Ishiyama et al. 2004] that is rooted in a deeper south-verging, out-of-sequence structure. The backthrust cuts through the Oligo-Miocene molassic sequence (Gonfolite Lombarda Group) and the overlying Pliocene marine sediments. The strain at higher levels is accommodated by the folding of the Quaternary deposits, including reflectors imaged at the shallowest levels on the seismic profiles (Figure 7).

Similarly, at Capriano del Colle hill, another fault-propagation fold formed above a north-verging backthrust (the Capriano del Colle backthrust; Figures 5, 6 and 7, CCB) ap- 


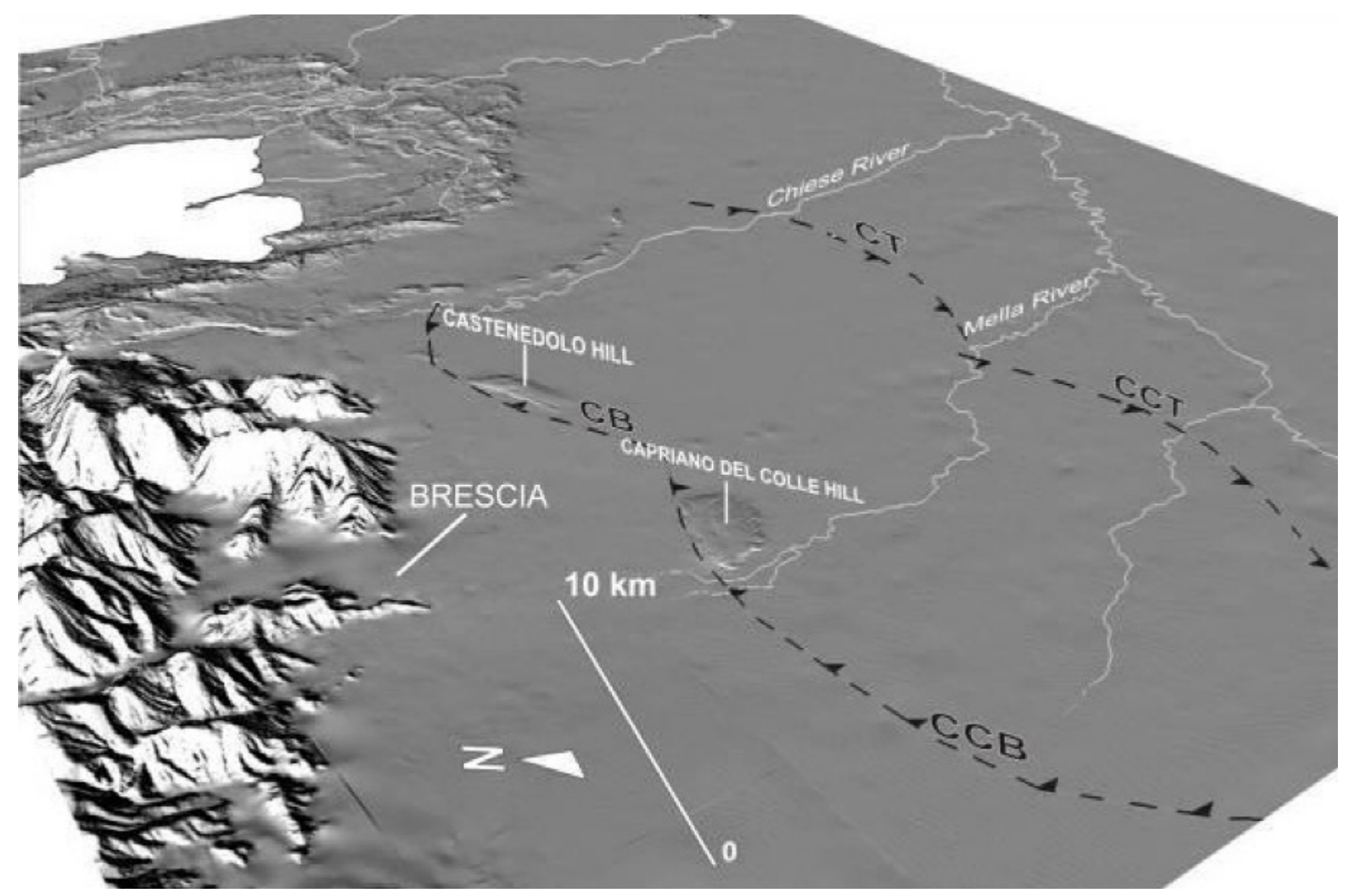

Figure 6. Three-dimensional perspective view of the Brescia area, focusing on the Castenedolo and Capriano del Colle fault systems. Note the Castenedolo and Capriano del Colle isolated hills. Vertical exaggeration, ca. 5x.

pears to be rooted in a main south-verging fore-thrust (the Capriano del Colle thrust; Figures 5, 6 and 7, CCT). The Quaternary deformation that propagates from the main deeper structure is accommodated by both the CCB and the forethrust. The CCT cuts the Oligo-Miocene sequence beneath a fault-propagation fold that gently deforms the above Plio-Pleistocene sequence.

The CT and CCT eventually merge downwards at the base of the Gonfolite Lombarda Group (ca. 5-6 km in depth), where slip can occur in response to the rheologically weaker level of the underlying upper Cretaceous to Eocene marls and flysch [Fantoni et al. 2004]. In map-view, the CT draws a ca. 15-km-long arc, which is bounded to the east by an inherited structural high (Figures 5 and 6). The CCT (ca. $10 \mathrm{~km}$ long) is segmented to the west into the Soncino structure (Figure 5, SON), a south-verging thrust that lacks any linked back-thrust [Burrato et al. 2003, Ravaglia et al. 2006].

Above the hangingwall anticlines of both the $\mathrm{CB}$ and the CCB, there are two isolated reliefs: the Castenedolo and the Capriano del Colle hills, respectively (the latter is also called 'Monte Netto'). Desio [1965] already interpreted the presence of these isolated areas of higher relief that are covered by ancient red soils (locally defined as ferretto) as the culmination of growing anticlines. The seismic reflection profile across Capriano del Colle hill (Figure 7b) clearly shows, for example, that the shallow active surface folding is geometrically linked to a secondary flexural-slip fault at a depth of ca. $2 \mathrm{~km}$, which is controlled in turn by the slip of the CCB at a depth of ca. $5 \mathrm{~km}$.

The Quaternary uplift history of these structures was investigated through analysis of the associated syn-growth depositional intervals, as documented in detail by Livio et al. [2009a, 2009b]. For the most recent time interval resolved through the available seismic data ( $0.89 \mathrm{Ma}$ to the present), Livio et al. [2009a, 2009b] calculated uplift rates of ca. 0.1 $\mathrm{mm} / \mathrm{yr}$ for both the Castenedolo and Capriano del Colle structures. Taking into account the deep fault and fold geometry illustrated by the depth-converted seismic lines 1 and 2 , this yields net slip rates of $0.4 \mathrm{~mm} / \mathrm{yr}$ to $0.5 \mathrm{~mm} / \mathrm{yr}$.

Quarry excavation at the Monte Netto site (Figure 8) allowed us to conduct preliminary paleoseismological analyses, which were supported by trenching and pedostratigraphic investigations [Livio et al. 2009b]. Two decametric secondary anticlines were exposed within a middle-to-late Pleistocene sequence of fluvial gravels and sands, paleosols, and loess deposits. The culmination of the northern anticline is characterized by a well-preserved paleoliquefaction feature and it is deformed by bending-moment faults (Figure 8 ) that offset 

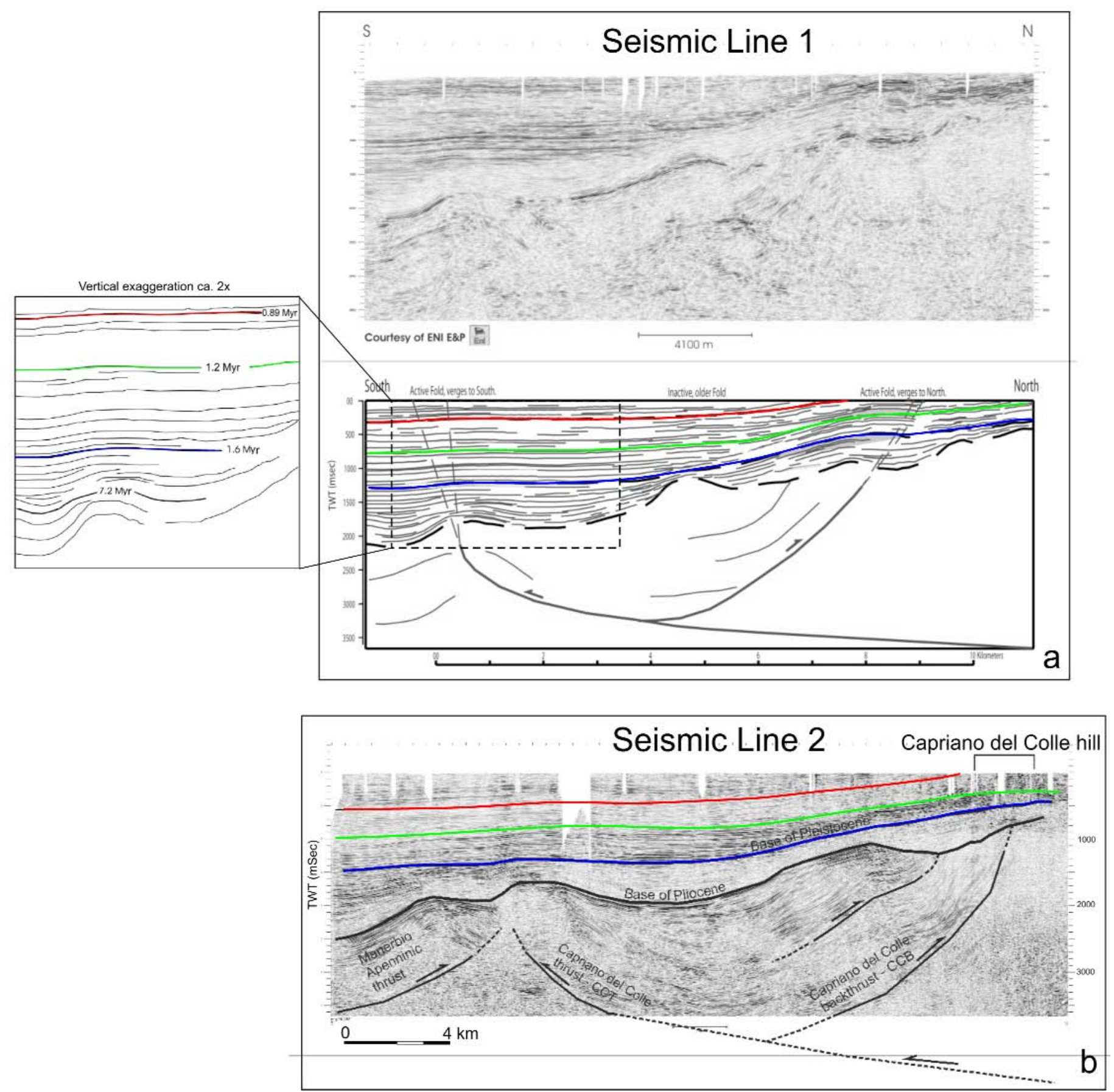

Figure 7. (a) Seismic section (top) and line drawing (bottom) along seismic line 1 of Figure 4a. The Castenedolo north-verging thrust affects the whole succession, faulting the Oligo-Miocene and probably part of the Pliocene, and folding all the above strata recognizable in the seismic profiles, up to the surface. (b) Interpreted seismic section along seismic line 2 of Figure 4a. The Capriano del Colle north-verging thrust affects the whole succession, with displacement of the Oligo-Miocene strata, and folding in the Plio-Quaternary sequence. The south-verging thrust is also interpreted to fault the OligoMiocene, and fold the overlying Plio-Quaternary strata. The Capriano del Colle hill is located on the surface projection of the north-verging thrust. A more detailed interpretation can be seen in Figure 3 of Livio et al. [2009b].

all of the sequence up to the Holocene surficial soil. Therefore, at this site, we can see the cumulative effects of repeated co-seismic surface deformation and displacement that are controlled at depth by late Pleistocene to Holocene slip along a major tectonic compressional structure (the CCB).

The maximum expected magnitude for compressional structures that are deforming at such low strain rates can be derived from an analysis of several scenarios of reactivation, including uncertainties related to each fault geometry. Con- sidering the subsurface fault length and width, the fault area and the net dip-slip rates, the range of derived $\mathrm{M}_{\mathrm{W}}$ for these structures can be estimated based on scalar relationships between fault parameters and maximum expected magnitudes [e.g., Wells and Coppersmith 1994]. Livio et al. [2009b] calculated a magnitude range derived for each single structure when considered as a seismogenic source. An additional scenario can be added if we also consider contemporary co-seismic rupturing of both the CCT and the CCB (which implies 

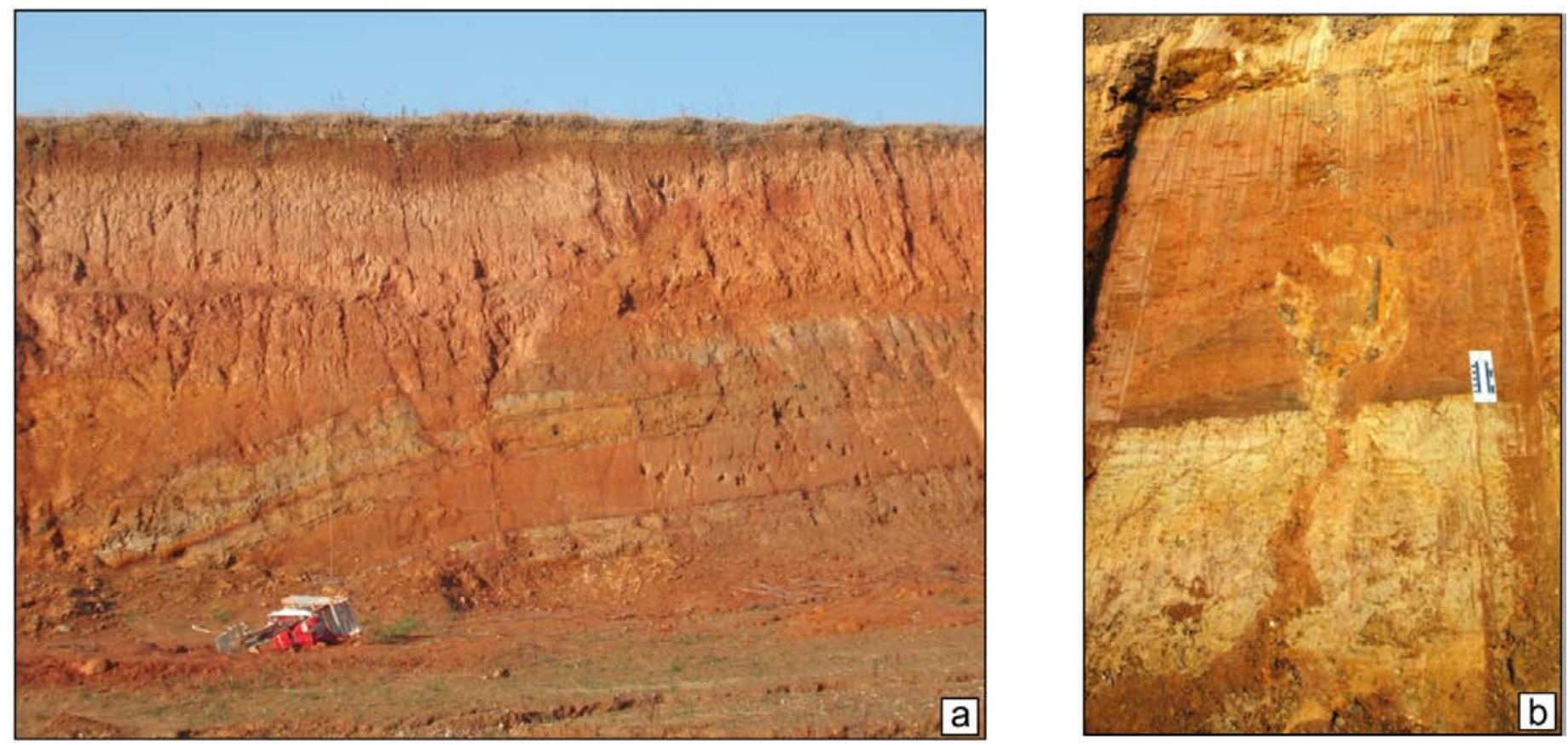

Figure 8. Details of the paleoseismic surface faulting (a) and liquefaction (b) exposed at Capriano del Colle hill in a quarry site [Livio et al. 2009b]. The size of the grid in (a) is $2 \mathrm{~m}$.

a rupturing area of ca. $600 \mathrm{~km}^{2}$ ). Indeed, many recent studies have explored co-seismic moment release and deformation during recent strong thrust earthquakes [e.g., Guzofski et al. 2007, Jia et al. 2010], and have demonstrated that significant deformation also occurs in the hangingwall and in the wedge sectors above the main roof thrust. Typically, these involve seismogenic rupture on both synthetic and antithetic fault planes.

Taking this inherent source complexity into account, the derived magnitude values can be expanded to a larger, but more conservative, interval of $\mathrm{M}_{\mathrm{W}}=5.9$ to 6.8. These values are also consistent with the maximum expected magnitudes derived for these structures by Serva [1990] $\left(\mathrm{M}_{\operatorname{Exp}}=\right.$ 6.8 for his "sistema Verona-Brescia") in the framework of the nuclear power plant siting research for northern Italy.

The area between Lakes Garda and Iseo has been characterized by moderate to strong earthquakes (Figure 1). The November 24, 2004, Salò earthquake $\left(\mathrm{M}_{\mathrm{L}}\right.$ 5.2) [Michetti et al. 2005b, Pessina et al. 2006], the causative structure of which is a part of the WSA, was the first significant event in the area for which a focal mechanism has become available, which showed a thrust-fault solution [Viganò et al. 2008] (Figure 1). The economic losses produced by this event were $>200$ million euro [Massimo Ceriani, Regione Lombardia, Protezione Civile, oral presentation at the Meeting Una Nuova Geologia per la Lombardia, November 7, 2008], and they demonstrate the vulnerability of the Lombardia urbanized and industrial setting also to such a low magnitude event. The town of Salò and its surroundings recorded considerable effects on buildings, infrastructure and the environment $\left(\mathrm{I}_{\mathrm{O}}=\right.$ VIII on the MCS and ESI 2007 scales) [Michetti et al. 2007]. The same area had already been hit by another earthquake of similar size, on October 30, 1901, which produced analogous damage and ground effects. Figure 9 compares the macroseismic intensity field of the November 24, 2004, Salò earthquake $\left(\mathrm{I}_{\mathrm{O}}=\right.$ VII-VIII MCS) [INGV 2004] with the intensity information available for the largest seismic event recorded in this area: the December 25, 1222, Brescia earthquake $\left(\mathrm{I}_{\mathrm{O}}=\mathrm{IX}-\mathrm{X}\right.$ MCS) [Magri and Molin 1986, Serva 1990, INGV 2000, Guidoboni 2002]. Despite the uncertainty that still exists around the 1222 event, its severity was noticeably much larger than for the 1901 and 2004 earthquakes.

Therefore, the stratigraphic and structural characteristics of the observed surface faulting and liquefaction at the Monte Netto site clearly show that these features were generated during strong local earthquakes. Indeed, similar environmental effects are typically associated with macroseismic intensities >IX on the MCS, the modified Mercalli, and the Medvedev-Sponheuer-Karnik scales [e.g., Serva 1996, Porfido et al. 2002, Michetti et al. 2007]. This is consistent with the environmental effects of an earthquake like the December 25, 1222, Brescia event.

\section{Case study 2: the western Lombardy-Insubria area}

Despite the low historical and instrumental seismicity [e.g., CPTI Workgroup 2004, Guidoboni et al. 2007] (Figure 1), evidence of Quaternary tectonic deformation has been repeatedly described in this area [e.g., Orombelli 1976, Bini et al. 1992, Zanchi et al. 1997] (Figure 10). In particular, recent studies by Chunga et al. [2007] and Sileo et al. [2007] presented new geological and geomorphological evidence of Quaternary tectonic shortening and paleoseismicity.

Field mapping and interpretation of unpublished seismic reflection data was carried out courtesy of ENI E\&P, and 

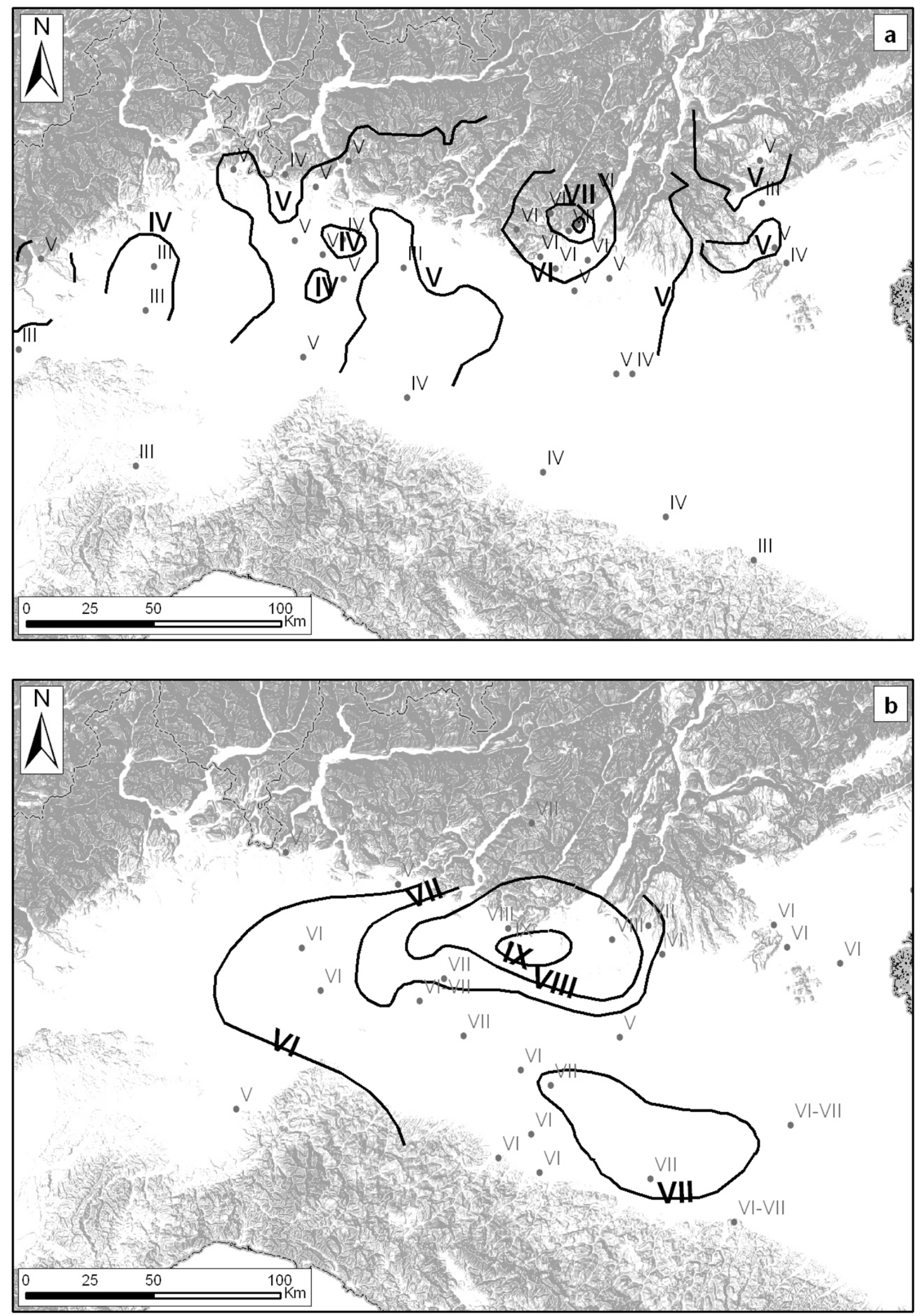

Figure 9. Intensity map (MCS scale) for the December 25th, 1222, Brescia earthquake (a) [after INGV 2000, Guidoboni 2002; modified] and the November 24, 2004, Salò earthquake (b) [after INGV 2004, modified]. 

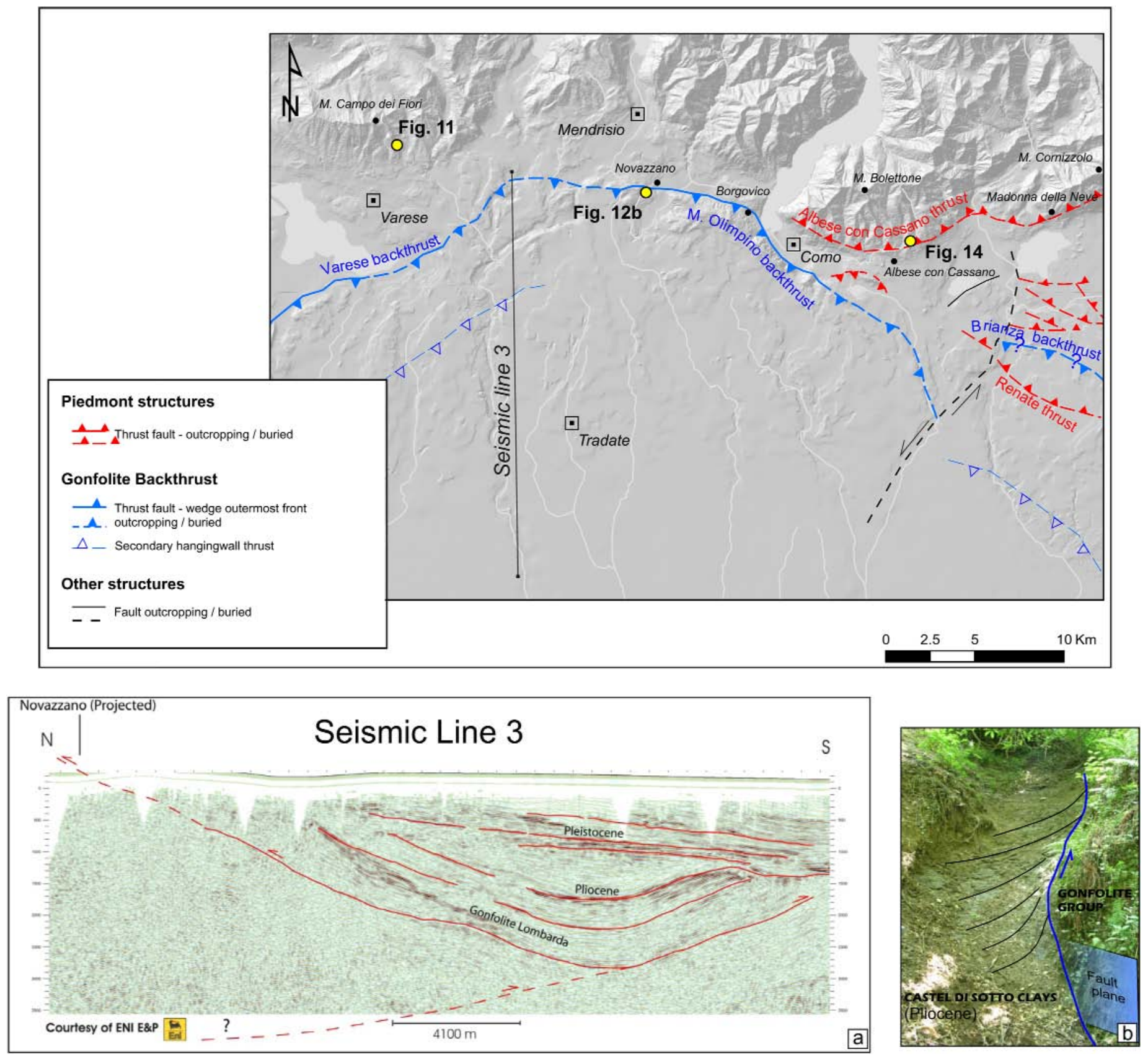

From top: Figure 10. Map of the main thrusts between Como and Varese. The outcropping thrusts are mapped based on geological surveys [Servizio Geologico d'Italia, in press] and geomorphology, while the buried fronts are from seismic reflection data. Seismic line 3 of Figure 4a is also shown. Yellow points show the locations of the photographs, as described in the indicated Figures. Figure 11. (a) Seismic reflection line 3, showing the Gonfolite backthrust, as given in Figure 10. Based on the seismic profiles, it is not possible to evaluate the recent activity because the Quaternary sediments are eroded on top of the north-verging thrust. Pliocene to Pleistocene activity in this case has been evaluated based on the outcrops of the fault between Novazzano and Como, and on the geomorphic evidence [Zanchi et al. 1997, Sileo et al. 2007] (Figure 10). (b) Detail of the Gonfolite backthrust at the Novazzano site. The Oligocene conglomerates of the Gonfolite Lombarda Gr. are juxtaposed against the dragged Pliocene clays of the Castel di Sotto Fm. The thrust is here deflected along the bedding and is progressively overturned upwards, with the topmost section of the fault showing a 'normal' sense of displacement.

these show that in this region the buried sector of the southern Alps is characterized by a major structure, the Gonfolite backthrust, which is rooted at the base of the Gonfolite Lombarda Group, at a depth of ca. 4-5 km (Figure 11) [e.g., Bernoulli et al. 1989]. This structure is segmented by ca. north-trending transfer faults, which act as lateral ramps or tear faults for each backthrust segment. The Mount Olimpino backthrust segment east of Novazzano, and the Varese backthrust to the west (Figure 10) generate steep and quite straight mountain fronts, and clearly control the geomorphology of the valley between Como and Mendrisio. The Mount Olimpino backthrust was initially interpreted by Bernoulli et al. [1989] as active until the Late Miocene. Sileo et al. [2007] documented evidence for this structure of reverse displacement in the Pliocene, with possibly younger deposits (Figure 11b). More recently, along the frontal sector of the Mount Olimpino backthrust, Livio et al. [2011] described late Pleistocene to Holocene offset of glacial and la- 
custrine deposits outcropping at the Borgo Vico site, in the metropolitan area of Como.

Similarly, at the western margin of the Varese backthrust, Bini et al. [1992] documented flexural slip faulting and paleoseismic features, such as broken speleothems and reverse displacement of phreatic conduits within the extensive karst systems of Mount Campo dei Fiori (Figure 12). U/Th dating of cave deposits constrain the age of these compressional deformations to the Pleistocene [Bini et al. 1992, Zanchi et al. 1997], and the last documented paleoseismic event occurred between $52.3 \pm 2.0$ and $5.5 \pm 0.5$ Ka B.P.

At Albese con Cassano, which is east of Como, the mountain front is bordered by a WSW-ENE trending ridge that is $5 \mathrm{~km}$ long (Figure 13, Albese con Cassano ridge). In this area, Orombelli [1976] and Zanchi et al. [1997] interpreted the Albese con Cassano ridge as a growing anticline that shows: (1) uplifted and faulted glacial to fluvioglacial middle-Pleistocene deposits (Figure 14); and (2) drainage diversion with the formation of a sequence of wind gaps.

Based on our investigation, the Piedmont belt between Como and Lecco is characterized by east-west-directed, southverging folds that deform the Mesozoic carbonatic sequence. Field mapping at a 1:10000 scale was performed for the new geological map of Italy (CARG Project, Geological Survey of Italy, Sheet n.75, 'Como'). This highlighted that at Albese con Cassano and Madonna della Neve (Figures 10 and 13), wellcemented, sub-horizontal polygenic conglomerates that overlay chaotic glacial till deposits crop out at elevations between $550 \mathrm{~m}$ a.s.l. and $600 \mathrm{~m}$ a.s.l. These deposits lie on the southernmost hills of the South Alpine mountain front, directly facing the northern fringe of the Po Plain, and they are locally cut by the morainic amphitheater of the Adda glacier. Based on stratigraphic correlations and on weathering profiles, these conglomerates were tentatively ascribed to the Mid-Pleistocene by Orombelli [1976]. This age is in agreement with the Mid-Pleistocene development of the most important frontal moraines of the Lake Como amphitheatre, while significant glaciations were apparently lacking during the late Pliocene and the early Pleistocene [e.g., Muttoni et al. 2003].

As discussed in detail by Sileo et al. [2007] and Chunga et al. [2007], and based on detailed field mapping and systematic sedimentological observations conducted for the CARG project, it has been possible to define the spatial distribution of these deposits. Facies analysis on these conglomerates clearly indicated a sandur-like environment (well-bedded, well-rounded gravel and sand of an open proglacial alluvial plain). In the field, it is possible to discriminate these glacial outwash plain fluvial conglomerates from the kame terrace deposits and from similar conglomerates formed at the margins of the ice tongue. These latter two are indeed characterized by more chaotic bedding, with less rounded and coarser components. Moreover, ice margin conglomerates and kame terrace deposits outcrop in very spe-

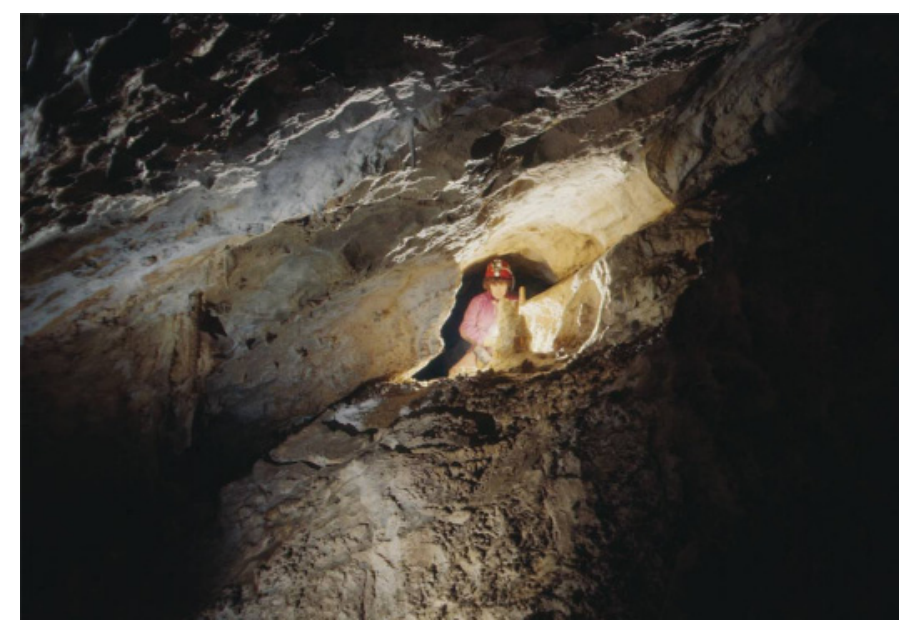

Figure 12. Displaced karstic channel in the Moltrasio Fm. Jurassic limestone at the Frassino Cave, Mount Campo dei Fiori, Varese. Bini et al. [1992] interpreted this feature as evidence of Pleistocene paleoseismicity related to co-seismic flexural slip on the Mount Campo dei Fiori thrust. Photograph courtesy of Paola Tognini.

cific settings, where the geomorphic relations with the feeding ice tongue are evident. On the contrary, the present topographic locations of the glacial outwash deposits at Albese con Cassano and Madonna della Neve do not show any obvious genetic relation with the local environment. These deposits are hanging on the southern slopes of Mount Bollettone and Mount Cornizzolo. They are $200 \mathrm{~m}$ higher than the top flat surface of the surrounding Piedmont belt, at an elevation that is higher than any other relief located to the south. Figure 13 clearly shows that the present location of the deposits is not consistent with their original depositional environment, and cannot be due to ancient paleo-morphologies or post-depositional erosion.

Correlative middle Pleistocene sandur deposits that outcrop in river gullies and are drilled by shallow exploratory boreholes dominate the flat Piedmont area at elevations lower than ca. $350 \mathrm{~m}$ a.s.l. The Piedmont plain just south of the Albese con Cassano hill is indeed part of the wide outwash plain, which is locally defined as the 'fundamental plain level' [Petrucci and Tagliavini 1969]. This formed during the last glaciation, and it now occupies the entire area between the southern margin of the Alps and the Po River [e.g., Marchetti 2002]. The polygenic conglomerates of the Albese con Cassano and Madonna della Neve sites thus represent the remnants of an ancient, Mid-Pleistocene, fundamental plain level that is now uplifted to ca. $200 \mathrm{~m}$ above the present outwash plain. We then propose that the Albese con Cassano hill is the surface expression of a fault-related anticline that has recorded ca. $200 \mathrm{~m}$ of vertical displacement from the middle Pleistocene to the present. If we assume an approximate age of $1 \mathrm{Ma}$ for the Albese con Cassano polygenic conglomerates, then this occurred at a cumulative uplift rate of ca. $0.2 \mathrm{~mm} / \mathrm{yr}$, which is a reasonable estimate in our opinion, based on the age of the first major glacial advance in the Alps [Muttoni et al. 2003]. 

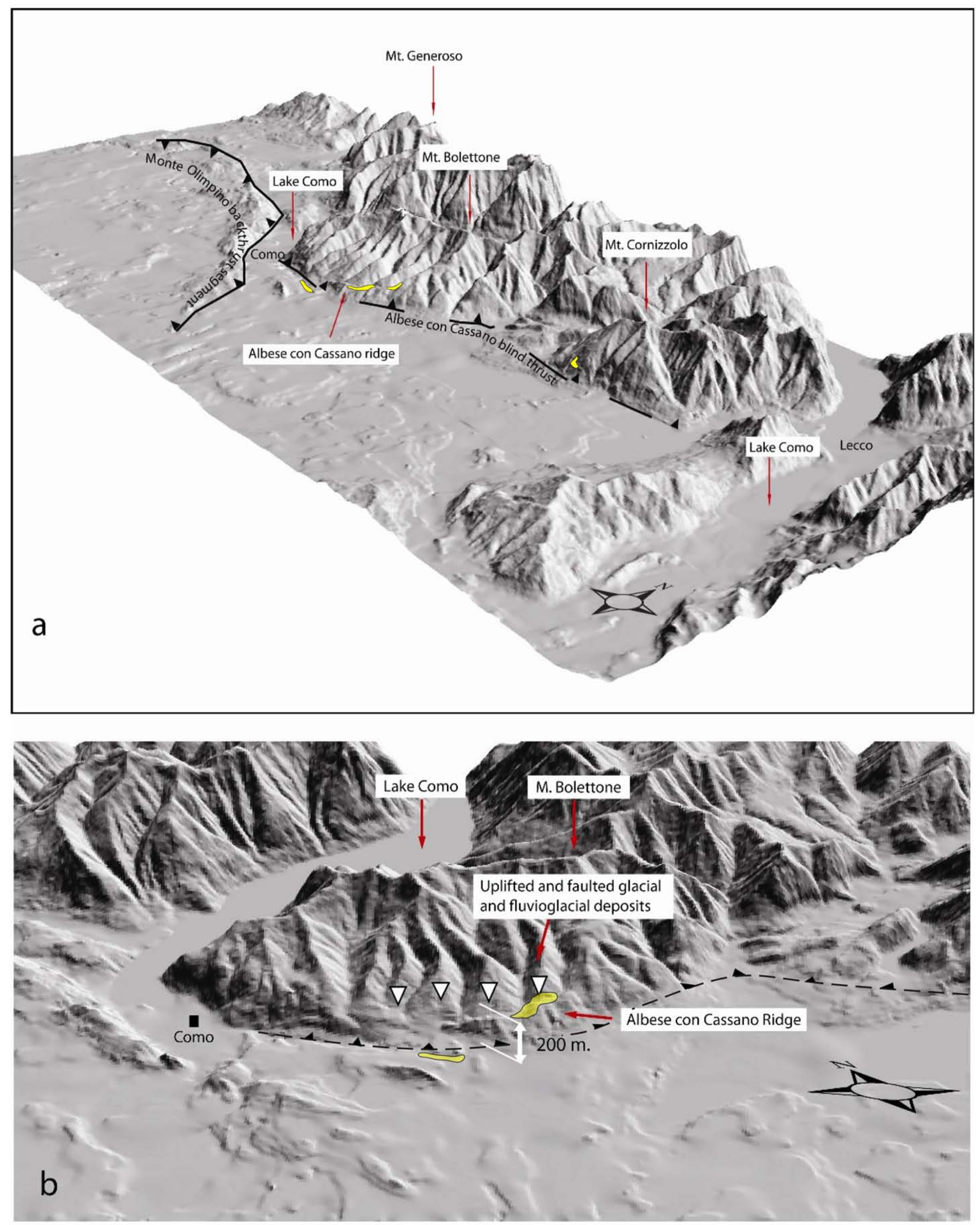

Figure 13. Three-dimensional perspective view of the Lake Como area and the adjoining glacial outwash plain. (a) View from the east showing the Albese con Cassano and Mount Olimpino thrusts, fronting each other near the city of Como. (b) View from the southeast of the Mount Bolettone area, showing the Albese con Cassano ridge, the Quaternary uplift of which (ca. $200 \mathrm{~m}$ ) dammed and diverted the local north-south trending drainage. The white triangles indicate the wind gaps. The yellow patches indicate the distribution of correlative fluvioglacial sediments in this area. 
We then created a forward evolution model to investigate the tectonic structures that might have accommodated uplift of part of the Mid-Pleistocene fluvioglacial plain, using structural and kinematics assumptions. These were derived from a trishear-like fault-propagation folding [e.g., Erslev 1991, Hardy and Ford 1997, Allmendinger 1998, Zehnder and Allmendinger 2000, Johnson and Johnson 2002]. We evaluated the possible deep fault-fold geometries, consistent with the surface geology of the Piedmont belt between Como and Lecco, using the Trishear 4.5 code that was developed by Richard Allmendinger at Cornell University, USA [Allmendinger 1998]. The best fit between the models and the mapped geology suggest that three faultpropagation folds developed in sequence from north to south, which splay from a single south-verging thrust at depths of ca. 2-3 km [Giardina 2006]. The southern-most fault-propagation fold caused uplift, but not tilting, of the Mid-Pleistocene polygenic conglomerates. This is possible in this case because of the geometry of the fold. Figure 15 shows a sketch model of the possible Quaternary evolution of the Albese con Cassano ridge.

The Albese con Cassano structure bounds the mountain front between Como and Lecco, and it is probably segmented into two 10-km-long, arc-shaped faults, as shown in Figure 13a. Structures similar to the Albese con Cassano ridge that have comparable length and slip rates in terms of active faults include Rough Ridge in New Zealand [Jackson et al. 2002].

Additional evidence for recent growth of these folds includes paleoseismic liquefaction features that are recorded in the Mid-Pleistocene pro-glacial lacustrine deposits that crop out on the Albese con Cassano anticline. These soft sediment deformations indicate that the region might have experienced significant strong ground motion, which is interpreted as being produced by local paleoearthquakes [Chunga et al. 2007].

\section{Case study 3: The Torino hill-Montferrato area}

The Monferrato arc has often been defined as the 'thrust frontale Padano' in the Italian literature (Figures 16 to 19 , TFP). It belongs to the northern sector of the Apennines and is located in the western-most Po Plain and bounded to the west and to the north by the western Alps, and to the south by the Ligurian Alps (Figure 1). In the western Po Plain, the AlpsApennines junction is characterized by a complex architecture. The metamorphic Penninic Units of the western Ligurian Alps are tectonically juxtaposed against the nonmetamorphic Ligurian Units of the Apennines, along an east-west-striking regional fault zone, just south of the Torino-Monferrato hills [e.g., Giglia et al. 1996, Mosca et al. 2009].

The Monferrato area exposes a sequence of Upper Eocene to Tortonian deposits, which lie on a substratum of Ligurian Units [Bonsignore et al. 1969]. Along the adjacent Torino hill there is an outcropping of a sequence of terrige-
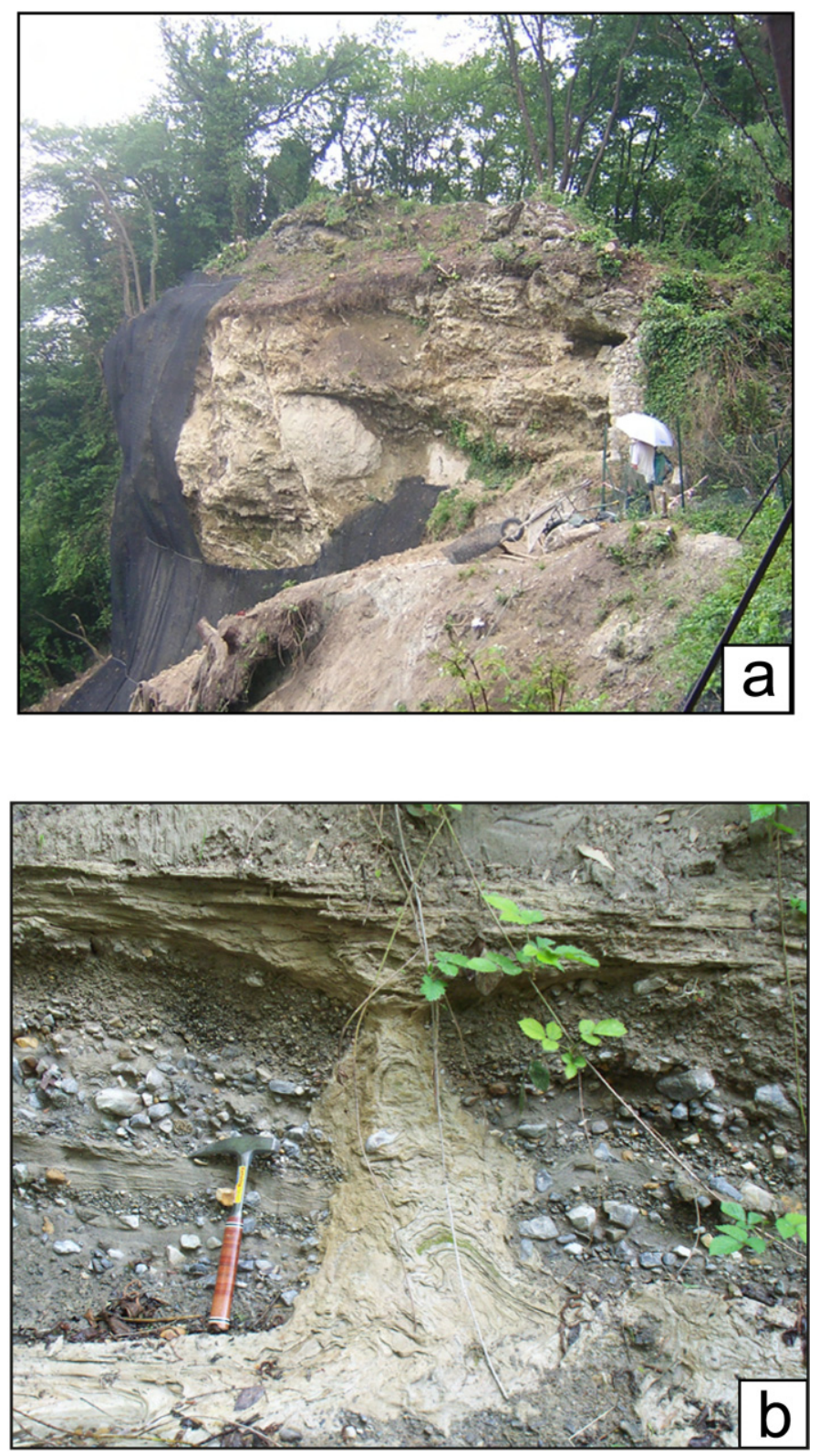

Figure 14. Albese con Cassano site. (a) High-angle reverse faulting in the Pleistocene glacial deposits. The vertical offset is ca. $5 \mathrm{~m}$. (b) Seismicinduced soft sediment deformation that affected a middle Pleistocene glaciolacustrine sequence.

nous units of the Upper Eocene to Tortonian. Torino hill lies on the hangingwall anticline of an out-of-sequence, northverging, breakthrough thrust. Conversely, beneath the Monferrato hills there has developed an important imbricate and north-verging thrust sheet. The Rio Freddo Deformation Zone is a north-west striking transpressive fault zone [Piana and Polino 1994, 1995], and it separates the Torino hill and Monferrato structures.

The available seismic lines highlight a considerable lowering of the tectonic activity since the Oligocene along the junction between the Alps and the Apennines, and a contemporary progressive activation of out-of-sequence, northverging thrusts from the west to the east [e.g., Falletti et al. 1995, Mosca et al. 2009]. These structures cut off older alpine thrusts along the so-called 'Torino hill structural belt' 

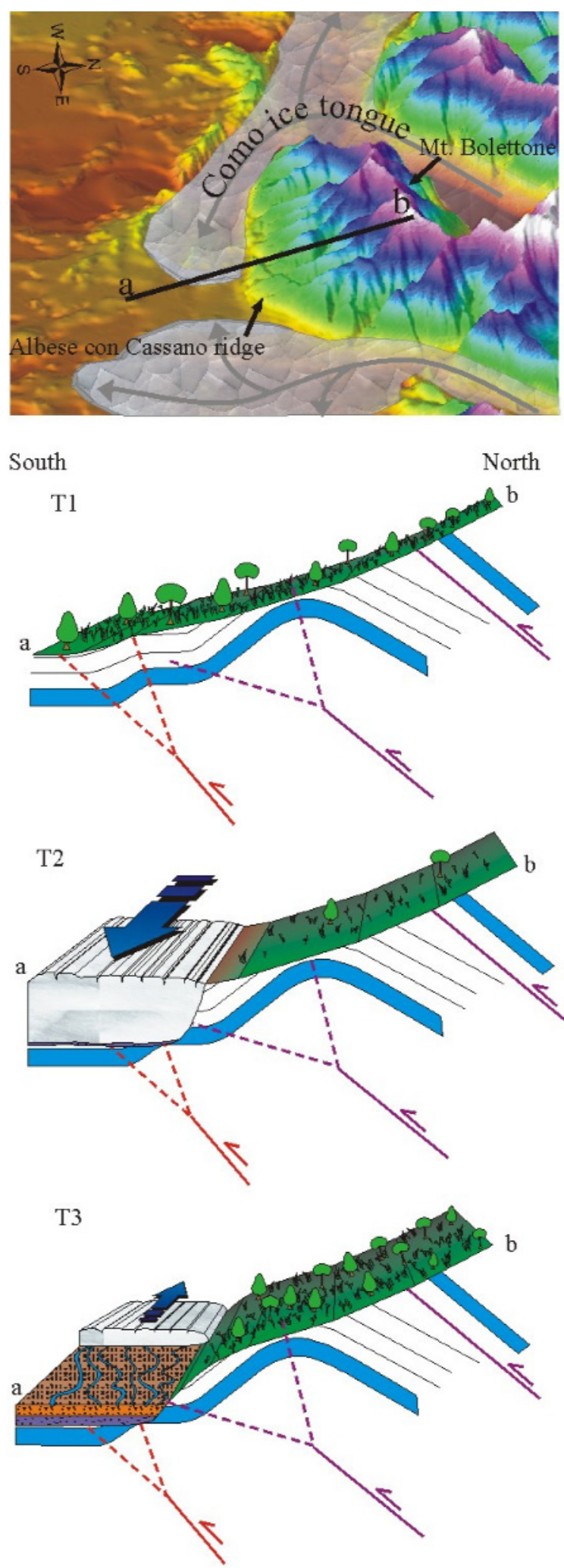
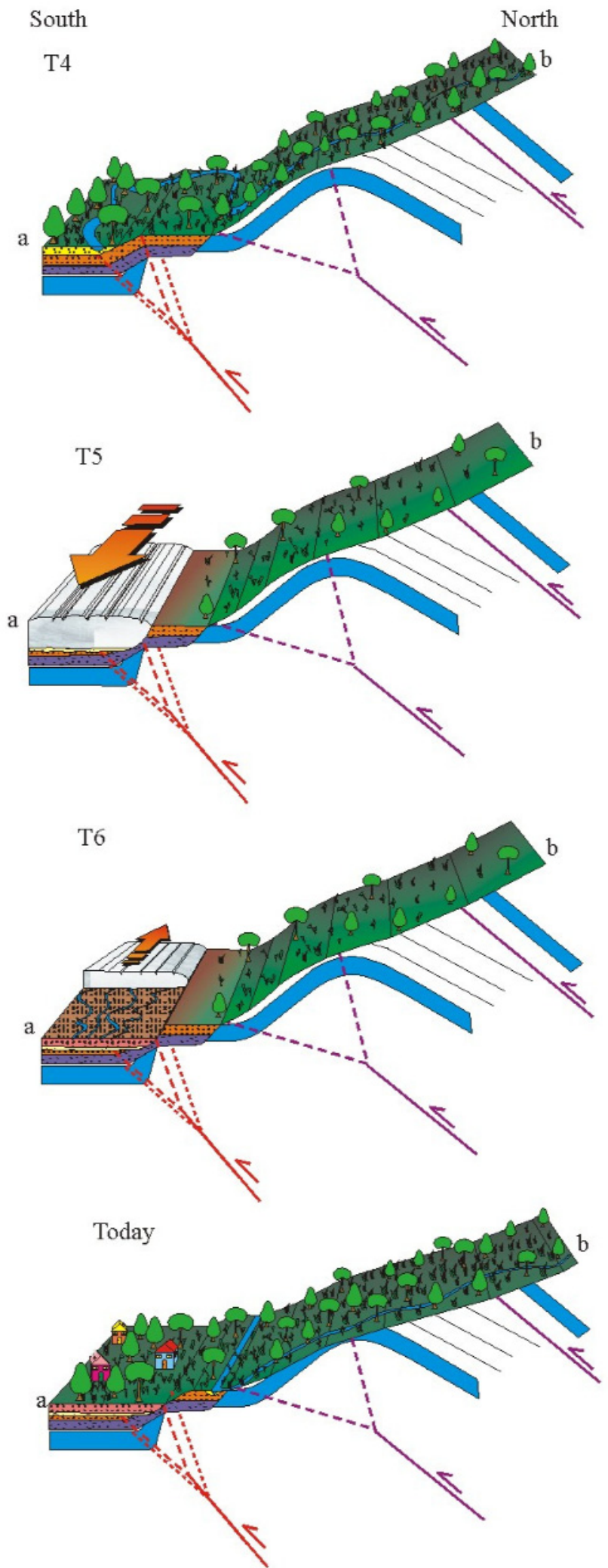

Figure 15. Cartoon of the possible Quaternary evolution of the Albese con Cassano growing anticline. The scheme shows a sequence of depositional and erosive events that repeated during the Mid-Pleistocene. The three-dimensional view of the Mount Bolettone area (top left) shows the possible ice tongue shape during one of the glacial events in the Mid-Pleistocene. The black line indicates the hypothetical profile trace.

[Mosca 2006] (Figures 16 and 17, TFP).

New data made available by the CARG project [Dela Pierre et al. 2003a, Dela Pierre et al. 2003b, Festa et al. 2009a, Festa et al. 2009b] clearly document the progressive off-set of stratigraphic units and geomorphic paleosurfaces across the TFP during the Pliocene and Quaternary, as already hypothesized by the pioneering study of Carraro et al. [1995].

Geomorphic evidence of recent activity can be found first of all in the isolated relief of Trino, which sticks out from the Po Plain just north of the Monferrato hills (Figure 18). 


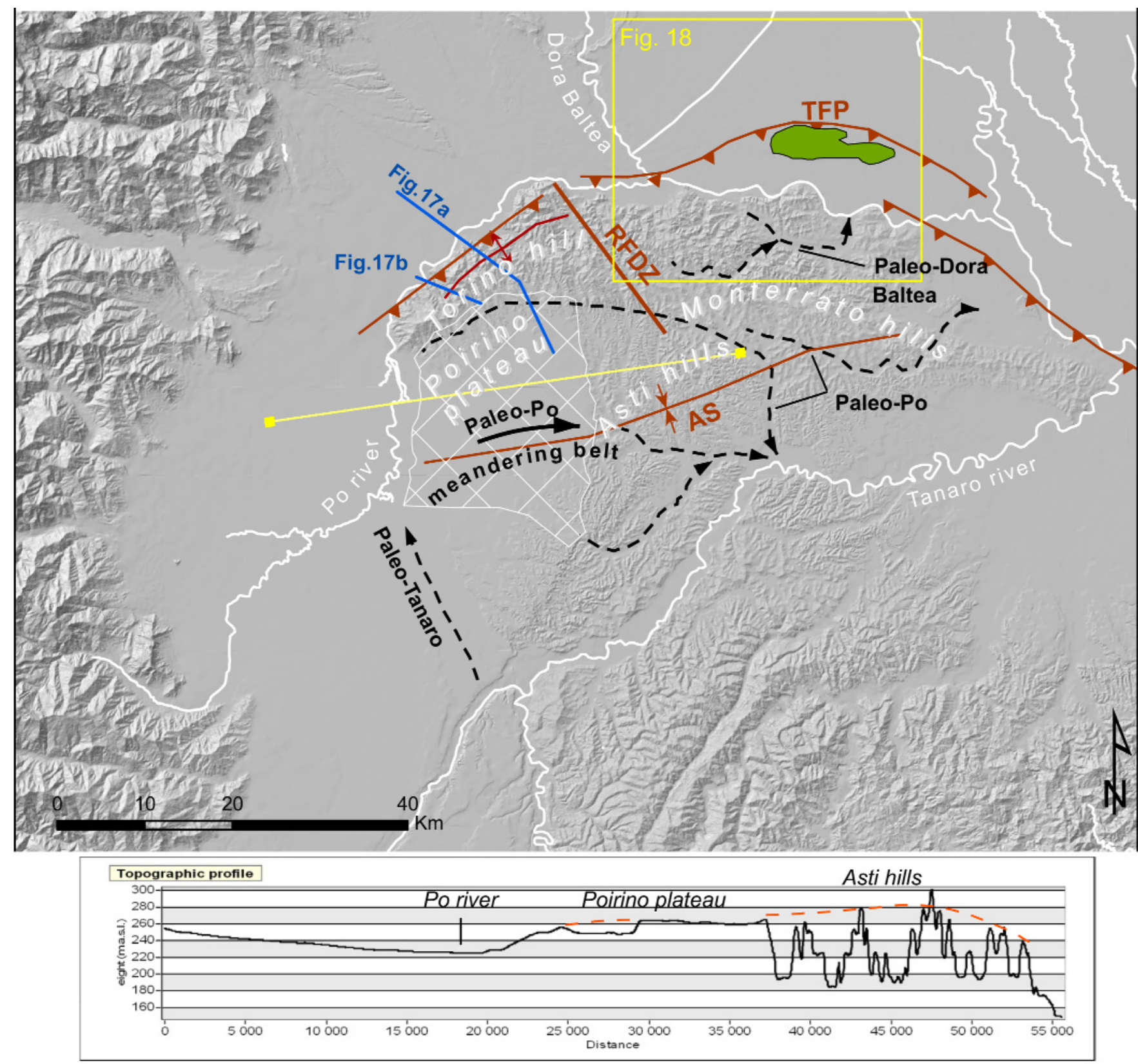

Figure 16. Shaded relief map of the Monferrato area. The main structures of the westernmost sector of the Monferrato arc are in red [modified after Mosca et al. 2009]. Black dashed arrows indicate the paleo-drainage recognized in this area (see text for details). The yellow line indicates the trace of the topographic profile shown in later Figures. The green area highlights Trino hill. Note that the area occupied by the paleo-Po river meandering belt has experienced at least $30 \mathrm{~m}$ of differential uplift. The red dashed line indicates a best fitting pre-erosive paleo-surface across the profile. Abbreviations: TFP, frontal north-verging thrust; RFDZ, Rio Freddo deformation zone; AS, Asti syncline.

The small Trino hill, which is only ca. 20 m higher than the surrounding alluvial plain, is actually the outcropping crest of a mostly buried anticline that belongs to the TFP [Gruppo di Studio del Quaternario Padano 1976]. Moreover, on the northern slope of Torino hill there are uplifted middle-to-late Pleistocene fluvial terraces and relics of meandering river courses [Vezzoli et al. 2010]. On this basis, Barbero et al. [2007] estimated an uplift rate of $0.8 \mathrm{~mm} / \mathrm{yr}$ to $1.0 \mathrm{~mm} / \mathrm{yr}$ (see Table in Figure 19). This is consistent with the geodetic leveling that was undertaken in the period of 1897 to 1957 , which identified a contemporary uplift rate of ca. $3 \mathrm{~mm} / \mathrm{yr}$ for the whole of the Torino hill sector [Arca and Beretta 1985]. Beneath the Torino metropolitan area, thrust faults that belong to the TFP reach the surface, and the bedrock in the hangingwall is generally only a few meters below the topographic surface (Figures 16 and 17). Above the bedrock, there is only a thin cover of Latest Pleistocene to Holocene fluvial sediments. In this case depositional and/or erosional processes have not kept pace with the tectonic uplift: in the inner sector of the range, the older features are progressively more uplifted, while in the adjacent sector of the plain, there are only incipient reliefs (e.g., the Trino isolated relief) or terraces.

A complex rearrangement of fluvial drainage during the Mid-Pleistocene to Holocene that included the combing and diverting of major rivers [e.g., Gruppo di Studio del Quater- 


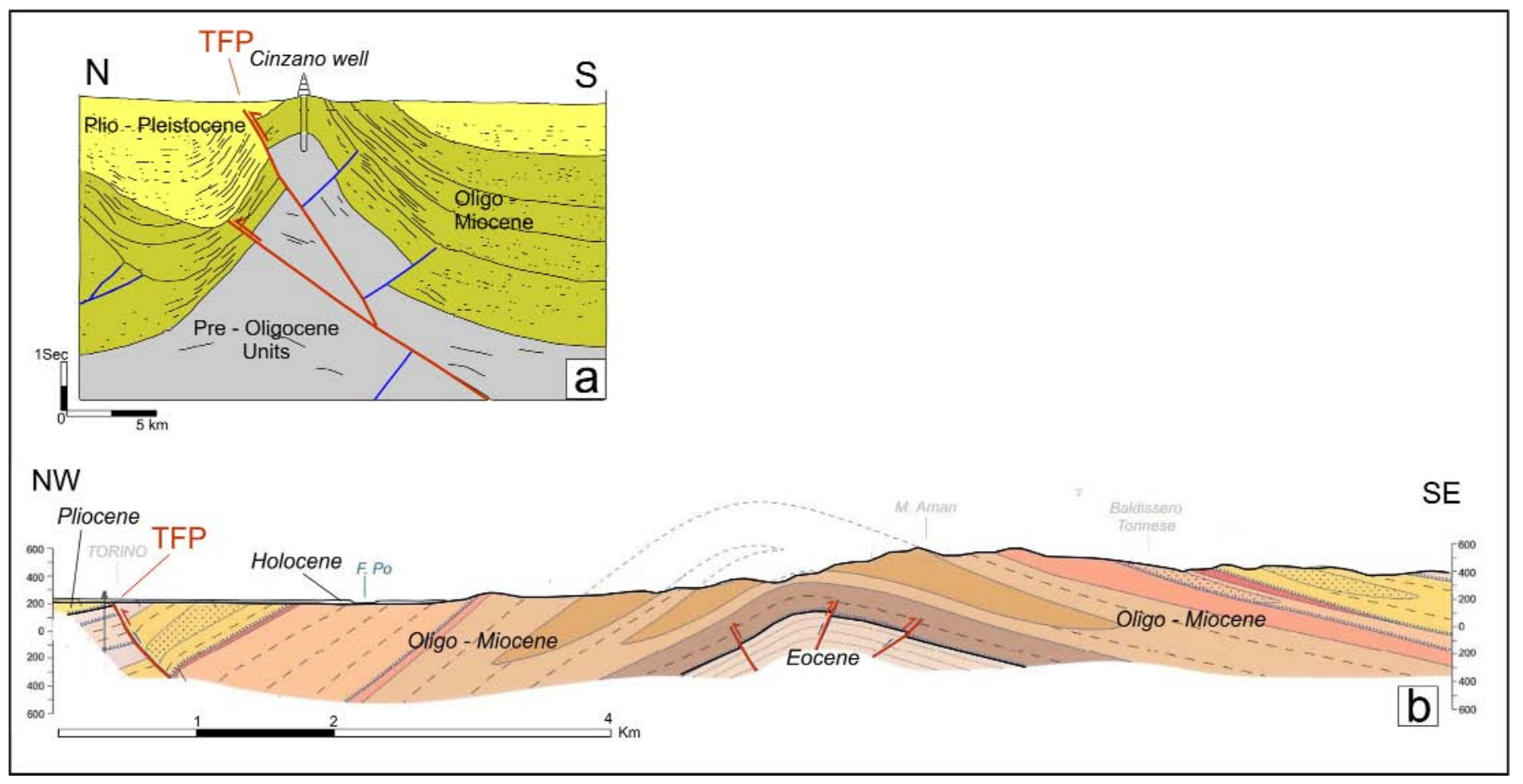

Figure 17. (a) Line drawing of the seismic line across the Torino hill sector interpreted by Mosca et al. [2009], modified and redrawn. (b) Geological crosssection across the Torino hill [redrawn after Festa et al. 2009a]. Note that the TFP cuts through the whole sedimentary sequence, probably also reaching and dislocating the Holocene alluvium. The cross-section locations are as indicated in Figure 16.

nario Padano 1976, Forno 1982, Dela Pierre et al. 2003b] testifies to the important recent tectonic activity of the TFP (Figure 16). For instance, the Cerrina Valley, which is located at the northern fringe of the Monferrato hills and is now drained by the Stura Stream, has to be related to a paleoDora Baltea River course that was successively diverted by the northward migration of the mountain front [e.g., Giraudi 1981, Carraro et al. 1995]. Fluvial deposits outcropping in the Cerrina Valley are related to a catchment located in the western Alps, and the valley morphology is clearly oversized compared with the present day Stura Stream flow rate (Figure 18b). Based on pedostratigraphy of the paleo-Dora Baltea fluvial deposits, the diversion is related to the beginning of the Mid-Pleistocene [Dela Pierre et al. 2003b]. The calculated minimum uplift rate is ca. $0.5 \mathrm{~mm} / \mathrm{yr}$ (see Table in Figure 19).

Until the end of the late Pleistocene, the Po River drained eastwards, south of the Torino and Monferrato hills (Figure 16). This is testified by: (a) the age of the oldest fluvial deposits, which are ascribed to the Po River, north of Torino hill: and (b) the clear traces of a huge meandering river that are preserved on Poirino Plateau [e.g., Carraro 1976, Forno 1982]. The Po River diversion was caused by the growing of west-plunging folds (Torino anticline and Asti syncline), the amplification of which caused a westwards tilting of Poirino Plateau itself. This tilting was initially compensated for by an eastwards increase in river erosion and by a progressive southwards migration of the meandering belt. Finally, the tilting won, and Po River was diverted north of
Torino hill. This tilting uplifted the western sector of Poirino Plateau by ca. $40 \mathrm{~m}$ to $60 \mathrm{~m}$ over a distance of ca. $20 \mathrm{~km}$ (Figure 16). The process can be indirectly dated to the Mid-Pleistocene, based on the Torino hill contemporary uplifting [Boano et al. 2004]. Moreover, a dated fluvial outcrop is located in the easternmost sector of the Poirino Plateau, which is ascribable to the course of a paleo-Po River. This post-dates the river diversion and the subsequent plateau erosion at 45 ka to 40 ka B.P. [Alessio et al. 1982]. The Po River diversion caused, in turn, a change in the Tanaro River course that was flowing from south to north and abruptly turned to the east just south of the Poirino plateau; the Tanaro River flows into the course of the ancient paleo-Po River just southeast of the Asti hills (Figure 16).

In the Torino hill and Monferrato area, therefore, unequivocal geological and geomorphic evidence demonstrate surface deformation and/or faulting at rates higher than those of the local depositional/erosional morphogenic processes. The relations between the tectonics and the sedimentation across the Monferrato arc, and the uplift rates estimated across the TFP at several locations, are illustrated in Figure 19, based on the recent revision published in Irace et al. [2009].

\section{Case study 4: the Mirandola structure-Ferrara arc}

The Mirandola structure is one of the recognized seismogenic sources that are buried below the Po Plain sediments. It is located at the western edge of a group of thrust-related folds that are defined as the Dorsale Ferrarese 

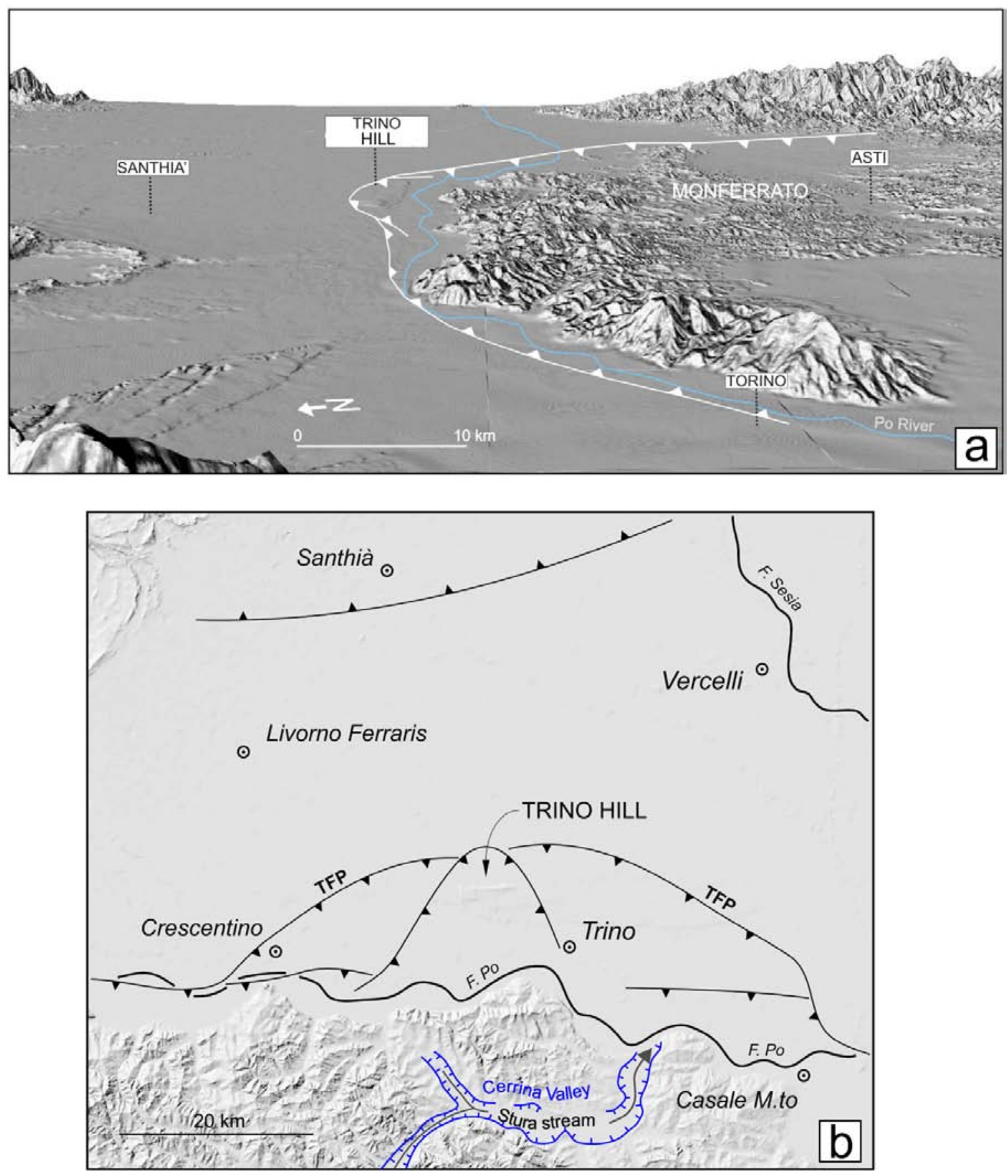

Figure 18. (a) Three-dimensional perspective view of the Torino hill and Trino isolated relief. (b) Shaded relief map of the Trino hill and northern Monferrato area, as indicted in Figure 16. The main structural features of the TFP are also shown. Note the paleodrainage of the Dora Baltea River along the current trace of the Cerrina Valley.

(Figure 20). The Mirandola structure represents the leading edge of the northern Apennines, and it began to develop from the early Pliocene. The Mirandola structure is considered a capable fault [e.g., ITHACA 2000, Burrato et al. 2003, Boccaletti et al. 2004, DISS Working Group 2005, Toscani et al. 2009, Boccaletti et al. 2011]. In particular, Scrocca et al. [2007] studied its Quaternary evolution in detail by integrating high-resolution stratigraphic data with other constraints related to the overall stratigraphic and structural architecture [AGIP 1959, 1977, Pieri and Groppi 1981, Nardon et al. 1990, Consiglio Nazionale delle Ricerche 1992, Regione Emilia Romagna and ENI-AGIP 1998, Baldi et al. 2009]. This thus provided an accurate description of the tectono-stratigraphic setting relative to the last $0.65 \mathrm{Ma}$.

The structural and stratigraphic architecture of the Mirandola anticline (Figures 20 and 21) strongly suggest a synsedimentary growth, with clear overlapping geometries also in Mid-to-Late Pleistocene times (i.e., sedimentation rates higher than uplift rates). As the geometry of the growth strata is certainly due to a combination of regional subsidence, sedimentation rates, eustatic history, tectonic uplift, and compaction effects, Scrocca et al. [2007] corrected the available stratigraphic data for compaction and compared the thickness of each stratigraphic interval at the crest of the an- 


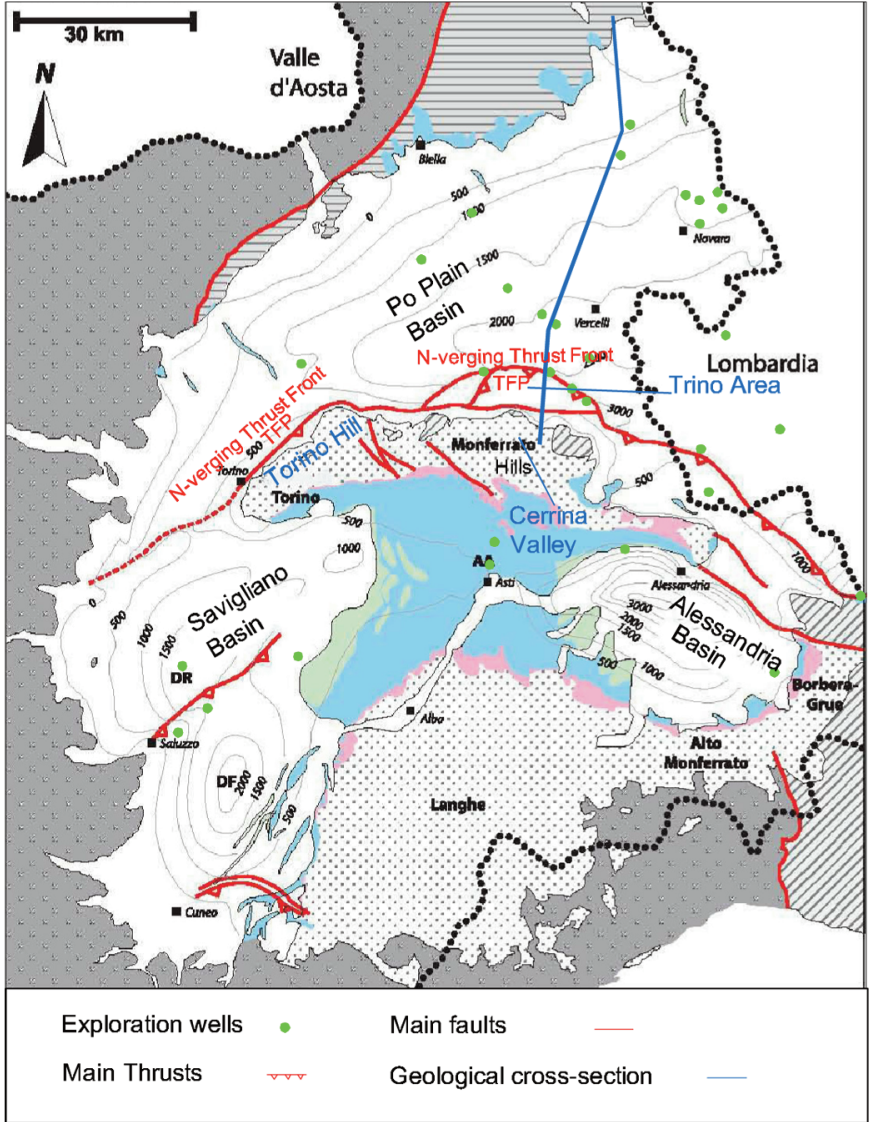

(modified after Irace et al., 2009)
Po Plain Basin

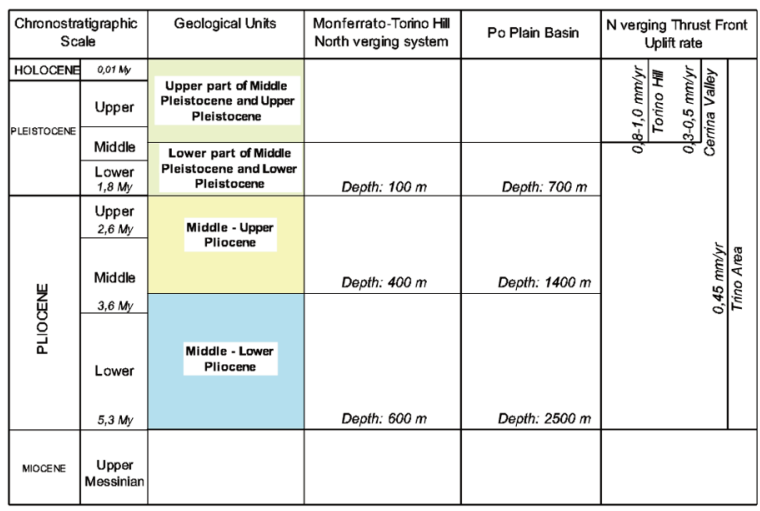

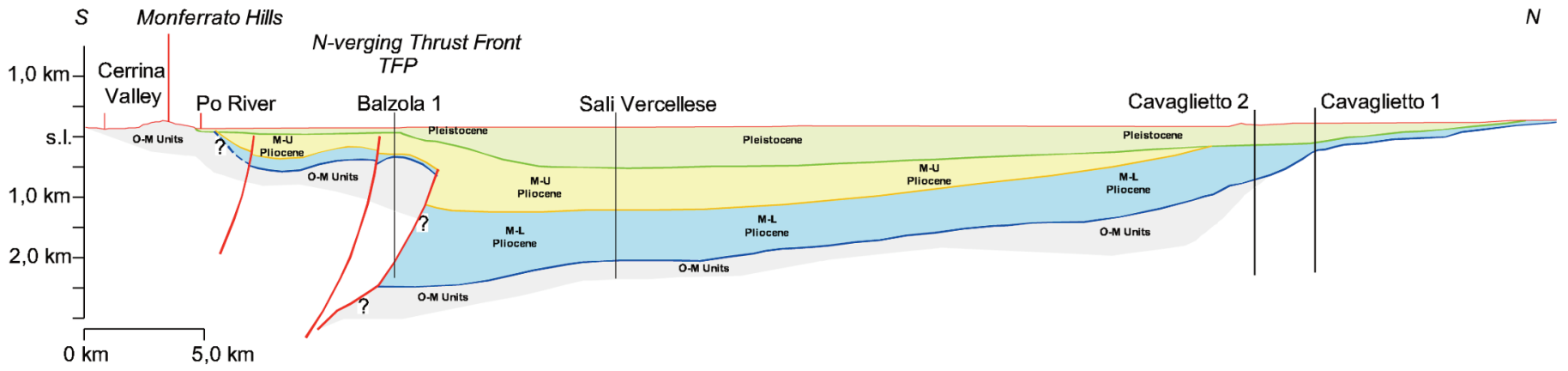

(modified after Irace et al., 2009)

Figure 19. Relationships between tectonics and sedimentation across the Monferrato arc during the Plio-Quaternary [modified after Irace et al. 2009], and related uplift rates over different sectors along the TFP, and over different Plio-Quaternary time windows. The geological cross-section of the Trino Area (Monferrato Hill eastern sector) is based on detailed lithostratigraphic (exploration wells) and geophysical (seismic lines) data, as fully described in Irace et al. [2009].

ticline and in the adjacent syncline. In this way, although this domain was affected by an overall regional subsidence, the Scrocca et al. [2007] estimated a tectonic 'relative uplift rate' between the fold crest and the adjacent syncline that was due to the tectonic activity of this thrust-related fold.

The resulting rates of tectonic uplift have decreased over the last $1.4 \mathrm{Ma}$, from $0.53 \mathrm{~mm} / \mathrm{yr}$ to $0.16 \mathrm{~mm} / \mathrm{yr}$. This means that the Mirandola anticline is still growing today, although it is moving more slowly than it did in the Pliocene. Before the May 20, 2012, earthquake, the Italian seismic catalog (Figure 20) did not report moderate to strong earthquakes for this area, except for the 1346 event, the location of which is, however, very poorly constrained.

Nonetheless, continuous surface fracturing and fissure opening has been reported for several localities along this structural high (i.e., at Correggio, above the Mirandola anticline, and at other sites along the Ferrara arc) [e.g., Pellegrini and Vezzani 1978] (Figure 20). A steady creeping behavior was invoked by Pellegrini and Vezzani [1978], even if other nontectonic causes might explain the observed features (i.e., differential compaction or extension along bending-moment faults, according to Carminati et al. 2010). If tectonic creep can be confirmed in further studies, this would be the only known case for the whole of the Po Plain foredeep. 


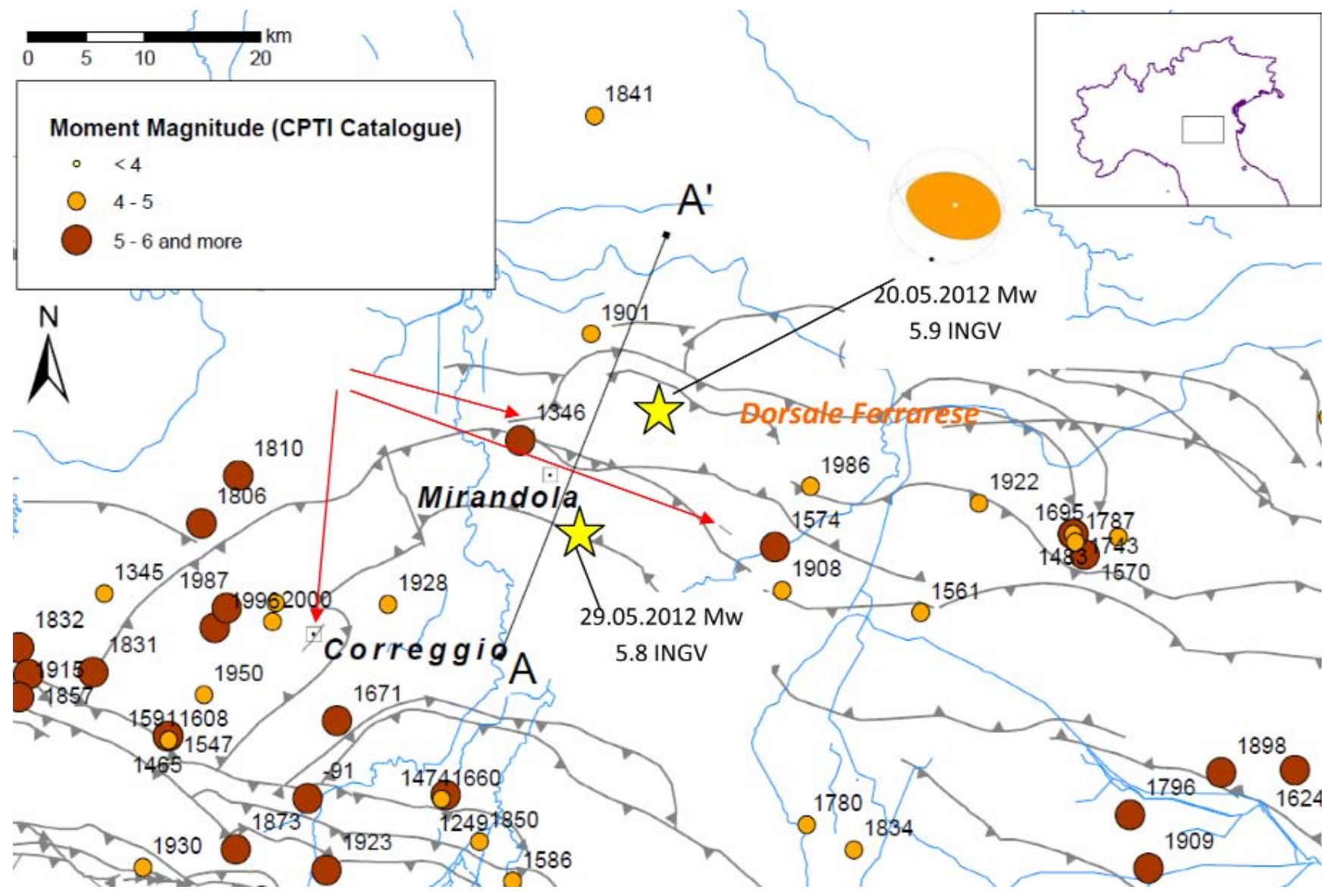

Figure 20. Capable faults [modified after ITHACA 2000], historical and instrumental seismicity [modified after CPTI Workgroup 2004] and drainage network in the epicentral area of the seismic sequence that initiated on May 20, 2012, along the Dorsale Ferrarese. The focal mechanism was from NEIC. Red arrows indicate the locations of surface rupturing and fissuring due to tectonic fault creep, according to Pellegrini and Vezzani [1978]. The trace of the seismic line interpreted in Figure $21\left(\mathrm{~A}-\mathrm{A}^{\prime}\right)$ is also shown.

A

Middle Pleistocene to recent $(0-0.65 \mathrm{Ma})$

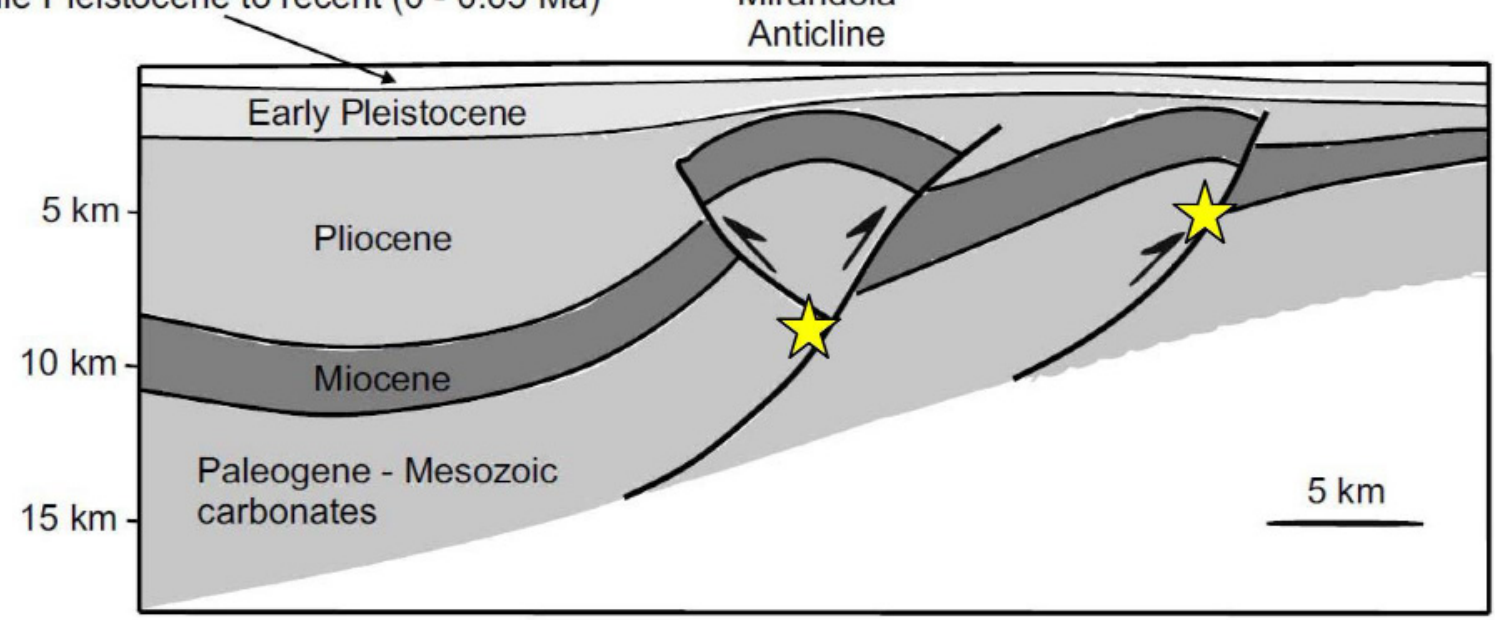

Figure 21. Simplified geological cross-section through the Mirandola anticline [modified after Scrocca et al. 2007], with very preliminary interpretation of the causative faults for the May 20 and 29, 2012, earthquakes. The stars show the tentative hypocentral locations. The trace of the cross-section (A $\mathrm{A}^{\prime}$ ) is as in Figure 20.

As already mentioned, the seismogenic potential of the Mirandola structure was dramatically illustrated by the May 20, 2012, $M_{W} 5.9$ [INGV 2012] earthquake and the ensuing seismic sequence. This occurred a few days after this review was accepted for publication. We were therefore invited to update our description of the Mirandola structure with some information on the earthquakes that occurred along the Dorsale Ferrarese using data that was available on June 3 , 2012 (see Figures 20 and 21 for preliminary locations of the two largest shocks) 


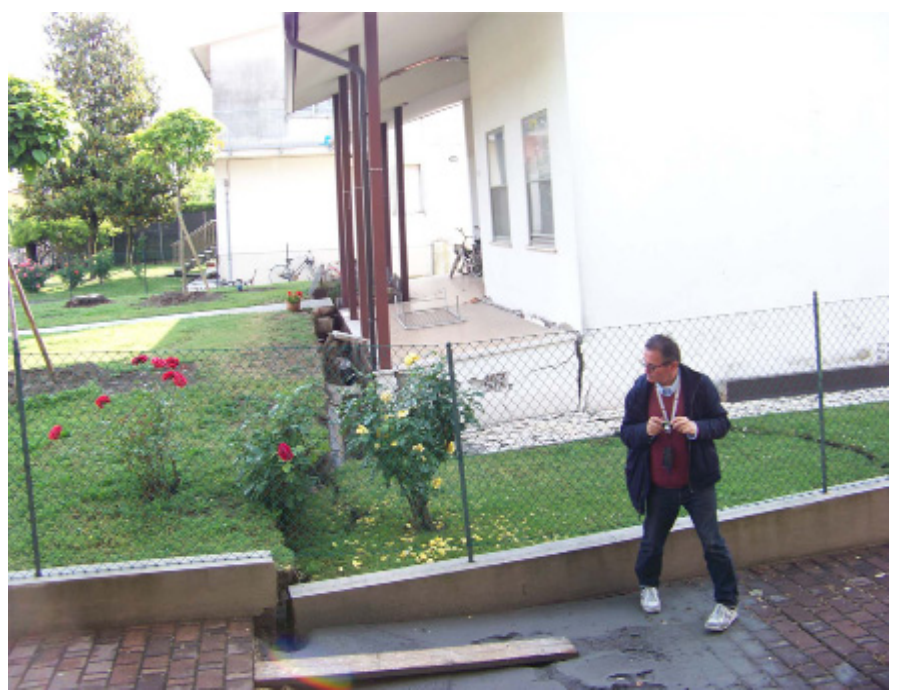

Figure 22. Environmental effects accompanying the May 20, 2012, $\mathrm{M}_{\mathrm{W}}$ 5.9, Finale Emilia earthquake. The ground failure associated to sand liquefaction at San Carlo, $30 \mathrm{~km}$ ESE of Mirandola. Doriano Castaldini shown for scale. The photograph was taken on May 21, 2012.

On Sunday, May 20, 2012, at 4.02 am in the night, local time, an earthquake of $\mathrm{M}_{\mathrm{W}} 5.9$ [INGV 2012] ruptured the Dorsale Ferrarese near Mirandola. The preliminary hypocentral depth was evaluated at ca. $6 \mathrm{~km}$ [INGV 2012]. A $\mathrm{M}_{\mathrm{W}} 5.8$ (focal depth ca. $9 \mathrm{~km}$ ) [INGV 2012] event occurred on May 29, 2012. The seismic sequence affected a WNW-ESE trending zone that was ca. $40 \mathrm{~km}$ long and was mainly located in the Emilia region. The available focal mechanisms (e.g., http:/ / www.bo.ingv.it/italiano/news/meccanismi-focalidella-sequenza-sismica-emiliana.html) clearly defined a NNE-SSW nearly pure compression. The focal depths generally range from very shallow to $10 \mathrm{~km}$ to $12 \mathrm{~km}$, with only a few deeper events that rarely exceeding $20 \mathrm{~km}$ in depth. The May 20, 2012, event occurred in an area of lower GPS strain rate with respect of the surroundings [Cuffaro et al. 2010], arguably testifying the presence of a locked fault segment. The death toll was 24 people (seven on May 20, 17 on May 29), and locally the damage was quite severe, and in particular in the historical downtown areas.

We visited the epicentral area from May 21, 2012, to map the environmental effects of the earthquake as part of a joint emergency team that included ISPRA, the INGV-Emergeo, the University of Insubria, the University of Modena (Doriano Castaldini), CNR-Firenze (Luigi Piccardi), Salamanca University, and the Spanish Geological Survey. Research is in progress to systematically survey the whole epicentral area, and to follow the evolution through time of the observed effects. The environmental effects observed to date have revealed a complex pattern of ground fractures that are mostly associated with ejected sand. Blue to gray fine sands from the fluvial network that crosses the epicentral area were extensively liquefied, to form fields of sand volcanoes; there have also been common reports in the area of water fountains up to $1.5 \mathrm{~m}$ high. At several sites, the ground water table has been reportedly up-lifted by several meters. The distribution of the ground failure and the liquefaction effects was essentially controlled by the local stratigraphic and geomorphic features. Indeed, the most severe effects occurred between Sant'Agostino and Mirabello, along a $6.5-\mathrm{km}$ narrow belt that follows the northeast-trending ancient embankment of the Reno River. This ancient embankment was artificially abandoned during the second half of the XVIII century, to mitigate local flood risk. Local ground failure and ground fractures damaged the water pipelines and the hydraulic irrigation network. In particular, near San Carlo, the liquefaction and lateral spreading phenomena were truly significant (Figure 22). The macroseismic intensity at San Carlo reached IX on the ESI 2007 scale. These phenomena showed a clear evolution through time, and this led to the progressive evacuation of most of the village. In general, it is possible to argue that the distribution and amount of damage in the epicentral area were largely controlled by the earthquake environmental effects, and especially the liquefaction and lateral spreading.

\section{Discussion and conclusions}

Based on internally consistent fault geometries, structural segmentation, and evidence for Quaternary surface and shallow subsurface folding strain, our investigations point to a coherent seismic landscape in the Po Plain foredeep [Serva 1996, Michetti and Hancock 1997, Michetti et al. 2005a].

The Po Plain is being actively shortened across a number of thrust and fault-related folds, as testified by GPS data and highlighted by geological and geomorphological evidence over a short-to-medium-length time window (Holocene to Mid-Pleistocene). As indicated by geodetic data on horizontal velocities, the tectonic strain is mainly taken up in the Piedmont sectors and by the buried structural fronts of the two opposite mountain chains. The vertical component of the strain is highlighted by recent tectonic landforms, such as isolated reliefs, fluvial diversions, tilted paleo-surfaces, and displaced fluvial terraces. These causative structures are typically moving at slip rates ranging between ca. 0.1 and $0.5 \mathrm{~mm} / \mathrm{yr}$ and are ca. 10 to $20 \mathrm{~km}$ long. Based on empirical regression relationships [e.g., Wells and Coppersmith 1994], they are capable of producing a maximum magnitude in the order of $\mathrm{M}_{\mathrm{W}}=6.0$ to 6.8 , and they might be characterized by long earthquake return periods (greater than 1000 yr) [e.g., Slemmons and DePolo 1986].

As an initial working model, it is thus possible to consider the December 25, 1222, Brescia earthquake $\left(\mathrm{M}_{\mathrm{E}}=6.2\right.$, according to Guidoboni and Comastri 2005) as a 'characteristic' earthquake for these structures, in terms of the earthquake magnitude and effects. This event can therefore be used as the reference earthquake that should be related to Quaternary structures that can produce surface faulting/ folding in the Po Plain foredeep. Further paleoseismological research is in progress to verify this hypothesis. 


\section{overturned thrust, deflected along bedding, showing "normal" sense of displacement} (Novazzano)

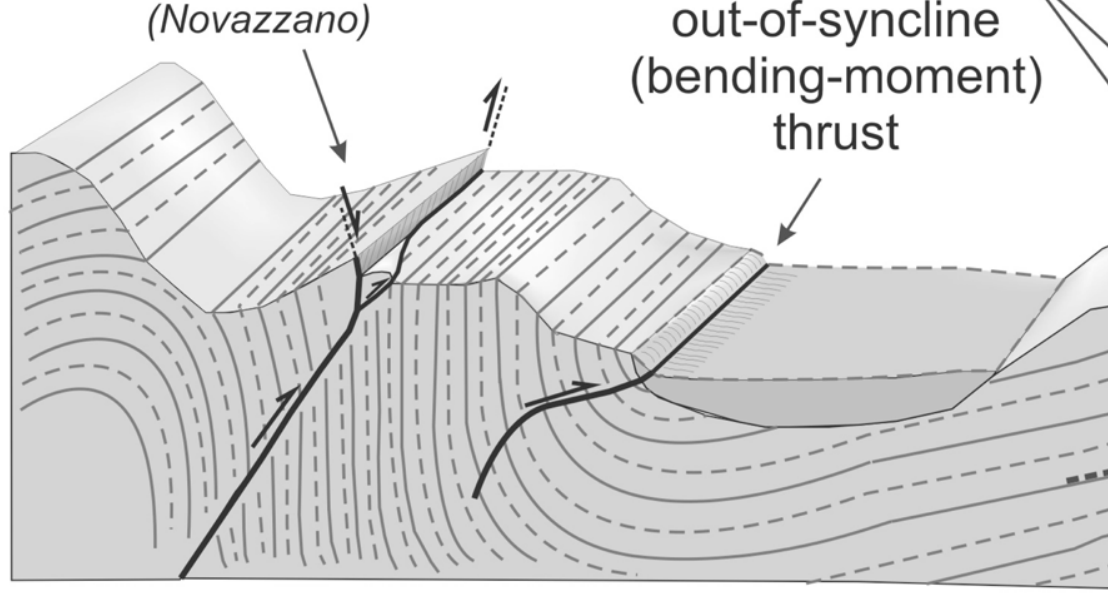

bending-moment faults gravity graben (Monte Netto) flexural-slip secondary "blind" thrust

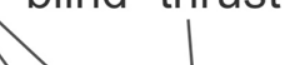

tear faulting along fault-propagation fold (Albese con Cassano)

Figure 23. Three-dimensional diagram showing some examples of the fold-related faulting that is typical of the Po Plain compressive tectonic setting [modified after Yeats 1986].

The case of the $M_{L}$ 5.2, November 24, 2004, Salò earthquake suggests instead that the size of earthquake can be considered as a 'floating' event for this area. As these kinds of earthquakes do not cause easily recognizable primary tectonic effects or other extensive ground effects in the studied tectonic setting, there are no clear criteria to associate a crustal earthquake of $M \leq 5$ to a specific tectonic structure. Therefore it is not possible at this stage to exclude that an earthquake in this range of magnitude can occur anywhere in this region.

Descending from the local seismic landscape, the resulting medium-to-long-term tectonic geomorphology is mostly dependent on local lithology and surface processes (i.e., sedimentation/ erosion rates, morphologic contrast), and on the regional style of faulting. The structural architecture of each fault zone is another important factor in the determination of the resulting geological and geomorphological tectonic imprint. As an example, in Figure 23 we summarize some typical structures of the Po Plain compressive environment, focusing in particular on fold-related faulting [e.g. Yeats 1986]. The specific features documented in the four case histories described above can be easily recognized.

In Figure 24, we propose a model that for the maximum expected magnitude threshold, illustrates the amount of surface faulting and the nature and distribution of co-seismic effects (primary and secondary) that are generally associated with typical earthquakes. The typical rupture length should range approximately from a few to two dozen kilometers. The model also accounts for secondary ground effects associated with the seismic events, such as landslides and liquefaction phenomena. Our study suggests that the central and western Po Plain mirrors these relations.

However, as stated before, local factors can mask the tectonic imprint on the landscape. These factors are essentially the rate of erosional and sedimentary processes, which are controlled by lithology, climate, and the shape of the drainage network. An ideal ratio between the tectonic $(T)$ and the local geological and geomorphological (G) morphogenic potentials (Figure 23, T/G) can easily express this concept. High ratios indicate an environment that is particularly promising for the preservation of tectonic features, while on the other hand, low ratios are typical of areas where sedimentation/ erosion tend to conceal/ erase the tectonic input.

Uplift rates can be considered a good proxy for $\mathrm{T}$. The case histories discussed in this review indicate that ca. $0.1 \mathrm{~mm} / \mathrm{yr}$ to $0.5 \mathrm{~mm} / \mathrm{yr}$ is a credible uplift rate for the whole of the investigated area. In eastern Lombardy, sedimentation was predominant at least until the latest glacial epoch. The sedimentation rates progressively lowered with the basin infilling, and they are estimated as $0.7 \mathrm{~mm} / \mathrm{yr}$ during the Jaramillo period, $0.35 \mathrm{~mm} / \mathrm{yr}$ during the Brunhes, and $0.15 \mathrm{~mm} / \mathrm{yr}$ thereafter, for a location ca. $6 \mathrm{~km}$ south of Castenedolo hill [Scardia et al. 2006]. After the last glacial maximum, no sedimentation was recorded in the northern fringe of the Po Plain, while active river entrenching and erosion was predominant.

Western Lombardy is characterized by a particularly conservative setting. Indeed, the Albese con Cassano site is located at a valley deflection and in a sector where the main ice tongues that repeatedly descended from the central Alps during the Quaternary resulted in a huge glacial lobe, thus losing a large part of their erosive potential. In the Monferrato area, the tectonic evolution is also revealed by the particularly emphasized morphological evolution. This appears to be connected to the low morphological contrast that characterizes this area, where dramatic changes in the drainage network occurred during the Mid-to-Late Pleistocene in response to 


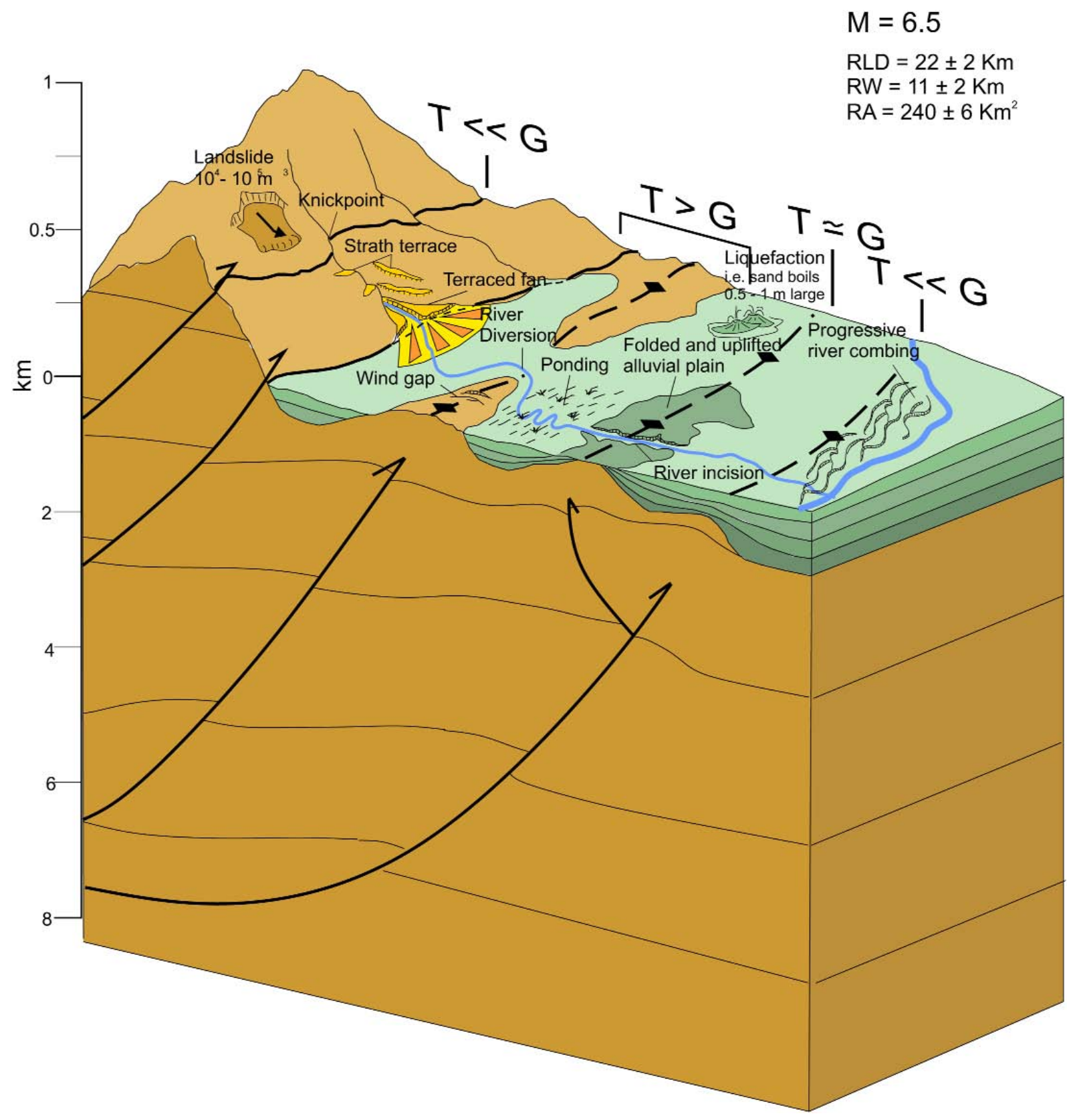

Figure 24. Schematic three-dimensional block diagram illustrating the typical seismic landscape in the Po Plain foredeep. Typical maximum earthquake size has been estimated as ca. $M=6.5$. The geometric parameters of the hypothetical seismogenic structure are shown, as derived from Wells and Coppersmith [1994]. The vertical exaggeration is ca. 4x. RLD, fault typical subsurface rupture length; RW, fault typical rupture width; RA, fault typical rupture area.

the growth of the Torino hill and Monferrato frontal thrusts.

Along the Mirandola anticline, the sedimentation rates were calculated over a time window from 1.4 Ma to the present [Scrocca et al. 2007]. The range of these calculated values is from $1.96 \mathrm{~mm} / \mathrm{yr}$ to $0.86 \mathrm{~mm} / \mathrm{yr}$, which is thus slightly greater than the corresponding uplift rates.

Indeed, the style and magnitude of the Quaternary tectonic deformation and its relation to the seismicity in this region are still relatively under-investigated topics. Although several studies have addressed this issue since the 1960's, there remains the lack of a systematic and integrated investigation based on modern active tectonics and paleoseismological techniques [e.g., Serva and Slemmons 1995, McCalpin 1996, Yeats et al. 1997, Michetti et al. 2005a, Audemard and
Michetti 2011]. A reasonably conservative seismic hazard assessment for the Po Plain should be based on the following conclusions:

- Although strong earthquakes similar to the intensity IX to X MCS historical events that occurred in 1117 and 1222 are very rare, they must be considered as credible events along all of the Quaternary faults throughout the whole Po Plain foredeep. This is necessary at least until we learn from geological and geophysical studies how/if the Quaternary tectonic structures near Brescia are truly different from those in other areas, such as, for example, the Monferrato arc, the Insubria region, and the Mirandola sector;

- Mid-Pleistocene to Holocene evidence of tectonic deformation is very well preserved throughout this investigated 
area from Emilia to Lombardia and Piemonte (see, for instance, the ITHACA database at http: / / www.isprambiente. gov.it/site/en-GB/Projects/ITaly_HAzards_from_CApable _faulting/default.html for a compilation of faults that show such evidence in the Po Plain). This has to be considered to be the result of the medium-to-long-term seismic history of this region. The tectonic aseismic creep that has been reported only for the Mirandola structure in the whole Po Plain has to be discussed and verified before aseismic behavior can be invoked for other areas where there remains a lack of recent strong earthquakes. Indeed, the tectonic fault creep on the same structure might be associated with the occurrence of strong earthquakes, as illustrated by the seismic sequence that started on May 20, 2012, and also along several other capable faults worldwide;

- The late Quaternary history of deformation, and especially that of the Holocene, and the local seismic landscape are far more valuable tools for the estimation of seismic hazard than has generally been appreciated previously in Italy, as well as in most parts of the world. The lack of significant earthquakes in the Garda region over the last eight centuries, and for longer elsewhere, must prompt efforts for a much deeper understanding of the present seismic potential in one of the most populated and economically developed areas of Europe.

On May 20, 2012, a few days after this review was formally accepted for publication, a $\mathrm{M}_{\mathrm{W}} 5.9$ [INGV 2012] earthquake ruptured the Mirandola structure. Observations from the seismic sequence following this mainshock substantially confirm our conclusions, as illustrated above. Active tectonics and paleoseismological data show that in terms of the maximum credible magnitude, the Po Plain, and therefore also the area affected by the present seismic sequence, is no different from other seismic areas of the Italian territory.

Acknowledgements. We are grateful to Carlo Doglioni for his support during the preparation of this manuscript and for the discussions about the active tectonics in the Po Plain foredeep. We are indebted to Doriano Castaldini, Luigi Piccardi, Luca Guerrieri, Andrea Berlusconi, Francesca Ferrario, Roberto Gambillara, and the colleagues of the INGV and ISPRA Teams who shared their results during the Emilia earthquake investigations.

\section{References}

AGIP Mineraria (1959). I giacimenti gassiferi dell'Europa occidentale. Accademia Nazionale dei Lincei.

AGIP Spa (1977). Temperature sotterranee, Ed. AGIP, San Donato Milanese.

Albarello, D., V. Bosi, F. Bramerini, A. Lucantoni, G. Naso,

L. Peruzza, A. Rebez, F. Sabetta and D. Slejko (2000).

Carte di pericolosità sismica del territorio nazionale, Quaderni di Geofisica, 12, 7 pp.+ 4 attachments (CDROM), Roma, INGV; available at http:/ / istituto.ingv.it/ l-ingv/produzione-scientifica/ quaderni-di-geofisica.

Albini, P., and A. Rovida (2010). The 12 May 1802 earthquake
(N Italy) in its historical and seismological context, J. Seismol., 14, 629-651; doi:10.1007/s10950-010-9187-6.

Alessio, M., L. Allegri, P. Ambrosetti, G. Bartolomei, F. Bella, G. Belluomini, G. Calderoni, F. Carraro, G. Charrier, C. Cortesi, D. Esu, M.G. Forno, S. Improta, L. Manfra and V. Petrone (1982). Il giacimento fossilifero pleistocenico superiore di Moncucco Torinese, Geogr. Fis. Dinam. Quat., 5, 219-239.

Allen, C.R. (1975). Geological criteria for evaluating seismicity, Geol. Soc. Am. Bull., 86, 1041-1057.

Allmendinger, R.W. (1998). Inverse and forward numerical modeling of trishear fault-propagation folds, Tectonics, 17, 640-656.

Amorosi, A., M. Farina, P. Severi, D. Preti, L. Caporale and G. Di Dio (1996). Genetically related alluvial deposits across active fault zones: an example of alluvial fan; terrace correlation from the upper Quaternary of the southern Po Basin, Italy. Sed. Geol., 102, 275-295.

Arca, S., and G.P. Beretta (1985). Prima sintesi geodetico-geologica sui movimenti verticali del suolo nell'Italia settentrionale (1897-1957), Boll. Geodes. Sci. Affini, 2, 125-156.

Argnani, A., M. Bernini, G.M. Di Dio, G. Papani and S. Rogledi (1997). Stratigraphic record of crustal-scale tectonics in the Quaternary of the northern Apennines (Italy), Il Quaternario, 10, 595-602.

Argnani, A., G. Barbacini, M. Bernini, F. Camurri, M. Ghielmi, G. Papani, F. Rizzini, S. Rogledi and L. Torelli (2003). Gravity tectonics driven by Quaternary uplift in the northern Apennines: insights from the La Spezia-Reggio Emilia geo-transect, Quat. Int., 101-102, 13-26.

Assereto, R., and P. Casati (1965). Revisione stratigrafica permo-triassica della Val Camonica meridionale (Lombardia), Riv. It. Pal. Strat., 71, 999-1097.

Audemard M., F.A. and A.M. Michetti (2011). Geological Criteria for Evaluating Seismicity Revisited: Forty Years of Paleoseismic Investigations and the Natural Record of Past Earthquakes, Geological Society of America Special Paper 479, 1-22.

Baldi, P., G. Casula, N. Cenni, F. Loddo and A. Pesci (2009). GPS-based monitoring of land subsidence in the Po Plain (Northern Italy), Earth and Planetary Science Letters, 288, 204-212.

Bally, A.W., L. Burbi, C. Cooper and R. Ghelardoni (1986). Balanced sections and seismic reflection profiles across the Central Apennines, Mem. Soc. Geol. It., 35, 257-310.

Barbano, M.S. (1993). Reassessing intensity of some Friuli earthquakes at the turn of the eighteenth century, Terra Nova, 5 (5), 467-474.

Barbero, D., P. Boano, M.T. Colla and M.G. Forno (2007). Pleistocene terraced succession, northern slope of Torino hill, Quaternary International, 171-172, 64-71.

Barrell, D.J.A., N.J. Litchfield, D.B. Townsend, M. Quigley, 
R.J. Van Dissen, R. Cosgrove, S.C. Cox, K. Furlong, P. Villamor, J.G. Begg, S. Hemmings-Sykes, R. Jongens, H. Mackenzie, D. Noble, T. Stahl, E. Bilderback, B. Duffy, H. Henham, A. Klahn, E.M.W. Lang, L. Moody, R. Nicol, K. Pedley and A. Smith (2011). Strike-slip ground-surface rupture (Greendale Fault) associated with the 4 September 2010 Darfield earthquake, Canterbury, New Zealand, Quarterly Journal of Engineering Geology and Hydrogeology, 44, 283-291; doi:10.1144/1470-9236/11-034

Bartolini, C., R. Caputo and M. Pieri (1996). Pliocene-Quaternary sedimentation in the Northern Apennine Foredeep and related denudation, Geological Magazine, 133 (3), 255-273.

Basili, R., G. Valensise, P. Vannoli, P. Burrato, U. Fracassi, S. Mariano and M.M. Tiberti (2008). The Database of Individual Seismogenic Sources (DISS), version 3: summarizing 20 years of research on Italy's earthquake geology, Tectonophysics, 453, 20-43.

Battaglia, M., M.H. Murray, E. Serpelloni and R. Burgmann (2004). The Adriatic region: an independent microplate within the Africa-Eurasia collision zone, Geophys. Res. Lett., 31, L09605.

Bello, M., and R. Fantoni (2002). Deep oil play in Po Valley: Deformation and hydrocarbon generation in a deformed foreland, AAPG Hedberg Conference Deformation History, Fluid Flow Reconstruction and Reservoir Appraisal in Foreland Fold and Thrust Belts (May 14-18, 2002, Palermo - Mondello, Sicily, Italy).

Benedetti, L., P. Tapponnier, G.C.P. King, B. Meyer and I. Manighetti (2000). Growth folding and active thrusting in the Montello region, Veneto, northern Italy, Journal of Geophysical Research, 105 (B1), 739-766.

Benedetti, L., P. Tapponnier, Y. Gaudemer, I. Manighetti and J. Van De Woerd (2003). Geomorphic evidence for an emergent active thrust along the edge of the Po Plain: the Broni-Stradella fault, Journal of Geophysical Research, 108 (B5), 2238; doi:10.1029/2001JB001546.

Bernoulli, D., G. Bertotti and A. Zingg (1989). Northward thrusting of the Gonfolite Lombarda ("South-Alpine Molasse") onto the Mesozoic sequence of the Lombardian Alps; implications for the deformation history of the Southern Alps, Eclogae Geologicae Helvetica, 82 (3), 841856.

Bernoulli, D., G. Bertotti and N. Froitzheim (1990). Mesozoic faults and associated sediments in the AustroalpineSouth Alpine passive continental margin, Memorie della Società Geologica Italiana, 45, 25-38.

Bersezio, R., E. Erba, M. Gorza and A. Riva (2002). Berriasian-Aptian black shales of the Maiolica formation (Lombardian Basin, Southern Alps, Northern Italy): local to global events. Palaeogeography, Palaeoclimatology, Palaeoecology, 180 (4), 253-275.

Bertotti, G., V. Picotti, D. Bernoulli and A. Castellarin (1993).
From rifting to drifting; tectonic evolution of the SouthAlpine upper crust from the Triassic to the Early Cretaceous, Sedimentary Geology, 86, 53-76.

Bertotti, G., R. Capozzi and V. Picotti (1997). Extension controls Quaternary tectonics, geomorphology and sedimentation of the N-Apennines foothills and adjacent Po Plain (Italy), Tectonophysics, 282, 291-301.

Bigi, G., D. Cosentino, M. Parotto, R. Sartori and P. Scandone (1990). Structural Model of Italy, Consiglio Nazionale delle Ricerche (CNR), Progetto Finalizzato Geodinamica, Quaderni de "La Ricerca scientifica", 114 (3), 1:500.000 scale, Firenze, SELCA.

Bini, A., Y. Quinif, O. Sules and A. Uggeri (1992). Evidences de tectonique récente dans les grottes du M. Campo de Fiori (Lombardie, Italie), Karstologia, 19, 23-30.

Boano, P., G.M. Forno and S. Lucchesi (2004). Pleistocene deformation of the Collina di Torino inferred from the modelling of their fluvial succession, Il Quaternario, 17 (2/1), 145-150.

Boccaletti, M., M. Coli, C. Eva, G. Ferrari, G. Giglia, A. Lazzaretto, F. Merlanti, R. Nicolich, G. Papani and D. Postpischl (1985). Considerations on the seismotectonics of the Northern Apennines, Tectonophysics, 117, 7-38.

Boccaletti, M., and L. Martelli, eds. (2004). Carta Sismotettonica della Regione Emilia-Romagna: Note Illustrative, Regione Emilia-Romagna, Servizio Geologico, Sismico e dei Suoli and CNR - Firenze, SELCA S.r.1., Firenze, 60.

Boccaletti, M., M. Bonini, G. Corti, P. Gasperini, L. Martelli, L. Piccardi, C. Tanini and G. Vannucci (2004). Seismotectonic Map of the Emilia-Romagna Region, 1:250000. Regione Emilia-Romagna - CNR.

Boccaletti, M., G. Corti and L. Martelli (2011). Recent and active tectonics of the external zone of the Northern Apennines (Italy), International Journal of Earth Sciences, 100 (6), 1331-1348; doi:10.1007/s00531-010-0545-y.

Bonsignore, G., G.C. Bortolami, G. Elter, A. Montrasio, F. Petrucci, U. Ragni, R. Sacchi, C. Sturani and E. Zanella (1969). Note Illustrative della Carta Geologica d'Italia alla scala 1:100.000, Fogli 56 e 57, Torino/Vercelli, 2nd ed., Serv. Geol. It., Roma, 96.

Boschi, E., E. Guidoboni, G. Ferrari, D. Mariotti, G. Valensise and P. Gasperini (2000). Catalogue of strong Italian Earthquakes from 461 B.C. to 1997, Annali di Geofisica, 43 (4), 609-868.

Burrato, P., F. Ciucci and G. Valensise (2003). An inventory of river anomalies in the Po Plain, Northern Italy: evidence for active blind thrust faulting, Annals of Geophysics, 46 (5), 865-882.

Burrato, P., M.E. Poli, P. Vannoli, A. Zanferrari, R. Basili and F. Galadini (2008). Sources of Mw 5+ earthquakes in northeastern Italy and western Slovenia: an updated view based on geological and seismological evidence, Tectonophysics, 453 (1-4), 157-176. 
Caporali, A., S. Martin and M. Massironi (2003). Average strain rate in the Italian crust inferred from a permanent GPS network; II, Strain rate versus seismicity and structural geology, Geophysical Journal International, 155/1, 254-268.

Carcano, C., and A. Piccin (2002). Geologia degli Acquiferi Padani della Regione Lombardia, Regione Lombardia and Eni Divisione Agip, 189, Firenze, S.EL.CA.

Carminati, E., C. Doglioni and D. Scrocca (2004). Alps vs. Apennines, Special volume of the Italian Geological Society for the IGC 32, Florence 2004, 141-151.

Carminati, E., D. Scrocca and C. Doglioni (2010). Compaction-induced stress variations with depth in an active anticline: Northern Apennines, Italy. Journal of Geophysical Research, 115, B02401.

Carraro, F. (1976). Diversione pleistocenica nel deflusso del bacino piemontese meridionale: un'ipotesi di lavoro, Gruppo Studio Quat. Pad., 3, 89-100.

Carraro, F., G. Collo, M.G. Forno, M. Giardino, F. Maraga, A. Perotto and D. Tropeano (1995). L'evoluzione del reticolato idrografico del Piemonte centrale in relazione alla mobilità quaternaria, In: R. Polino and R. Sacchi (eds.), Atti del Convegno "Rapporti Alpi-Appennino" e guida alle escursioni (May 31-June 1st 1994, Peveragno, CN, Italy), Acc. Naz. Sc., Roma, 14, 445-461.

Castellarin, A., and R. Sartori (1983). Il sistema tettonico delle Giudicarie, della Val Trompia e del sottosuolo dell'alta pianura lombarda, Mem. Soc. Geol. Ital., 26, 31-37.

Castellarin, A., C. Eva, G. Giglia, G.B. Vai, E. Rabbi, G.A. Pini and G. Crestana (1985). Analisi strutturale del Fronte Appennico Padano, Giornale di Geologia, 47 (1-2), 47-75.

Castellarin, A., and G.B. Vai (1986). Southalpine versus Po Plain Apenninic arcs, In: F.C. Wezel, The origin of arcs, Development in Geotectonics, 21, 253-280.

Castellarin, A., L. Cantelli, A.M. Fesce, J.L. Mercier, V. Ricotti, G.A. Pini, G. Prosser and L. Selli (1992). Alpine compressional tectonics in the Southern Alps; relationships with the N-Apennines, Annales Tectonicae, 6 (1), 62-94.

Castellarin, A., and L. Cantelli (2000). Neo-Alpine evolution of the Southern Eastern Alps, Journal of Geodynamics, 30 (1-2), 251-274.

Castellarin, A., and Transalp Working Group (2004). Structural synthesis of the Eastern Alps: a collisional orogenic chain, Special volume of the Italian Geological Society for the IGC 32, Florence, 3-13.

Castellarin, A., G.B. Vai and L. Cantelli (2006). The Alpine evolution of the Southern Alps around the Giudicarie faults: A Late Cretaceous to Early Eocene transfer zone, Tectonophysics, 414, 203-223.

Chunga, K.A., F. Livio, A.M. Michetti and L. Serva (2007). Synsedimentary deformation of Pleistocene glaciolacustrine deposits in the Albese con Cassano Area (Southern Alps, Northern Italy), and possible implications for pale- oseismicity, Sedimentary Geology, 196, 59-80.

Consiglio Nazionale delle Ricerche (1992). Structural Model of Italy and Gravity Map, Quaderni de "La Ricerca Scientifica", 114 (Progetto Finalizzato Geodinamica, vol. 3).

CPTI Workgroup (2004). Catalogo Parametrico dei Terremoti Italiani, version 2004 (CPTI04), INGV, Milan; available at http: / / emidius.mi.ingv.it/CPTI/

Cuffaro, M., F. Riguzzi, D. Scrocca, F. Antonioli, E. Carminati, M. Livani and C. Doglioni (2010). On the geodynamics of the northern Adriatic plate, Rend. Fis. Acc. Lincei, 21, Supplement 1, S253-S279; doi:10.1007/s12210010-0098-9.

D'Agostino, N., D. Cheloni, S. Mantenuto, G. Selvaggi, A. Nichelini and D. Zuliani (2005). Strain accumulation in the Southern Alps (NE Italy) and deformation at the North Eastern boundary of Adria observed by CGPS measurements, Geophysical Research Letters, 32, L19306.

Dela Pierre, F., F. Piana, P. Boano, G. Fioraso, M.G. Forno, R. Polino and P. Clari (2003a). Carta Geologica d'Italia alla scala 1:50.000, Foglio 157 "Trino", APAT, Agenzia per la Protezione dell'Ambiente e per i Servizi Tecnici - Dipartimento Difesa del Suolo, Roma.

Dela Pierre, F., F. Piana, G. Fioraso, P. Boano, E. Bicchi, M.G. Forno, D. Violanti, P. Clari and R. Polino (2003b). Note illustrative della Carta Geologica d'Italia alla scala 1:50.000, Foglio 157 "Trino", APAT, Agenzia per la Protezione dell'Ambiente e per i Servizi Tecnici - Dipartimento Difesa del Suolo, Roma, 147 pp.

Desio, A. (1965). I rilievi isolati della pianura Lombarda ed i movimenti tettonici del Quaternari, Rendiconti dell'Istituto Lombardo, Accademia di Scienze e Lettere, Sezione A, 99, 881-894.

Devoti, R., A. Esposito, G. Pietrantonio, A.R. Pisani and F. Riguzzi (2011). Evidence of large scale deformation patterns from GPS data in the Italian subduction boundary, Earth Planet. Sci. Lett., 311, 230-241.

Di Bucci, D., and S. Mazzoli (2002). Active tectonics of the Northern Apennines and Adria geodynamics: new data and a discussion, J Geodyn., 34, 687-707.

DISS Working Group (2005). Database of Individual Seismogenic Sources (DISS), Version 3.0.1: A compilation of potential sources for earthquakes larger than M 5.5 in Italy and surrounding areas; http: / / www.ingv.it/DISS /, (C) INGV 2005 - Istituto Nazionale di Geofisica e Vulcanologia - All rights reserved).

Doglioni, C., and A. Bosellini (1987). Eoalpine and mesoalpine tectonics in the Southern Alps, Geol. Rundschau., 76, 735-754.

Doglioni, C. (1992). Relationships between Mesozoic extensional tectonics, stratigraphy and Alpine inversion in the Southern Alps, Eclogae Geologicae Helvetiae, 85 (1), 105-126. 
Doglioni, C. (1993). Some remarks on the origin of foredeeps, Tectonophysics, 228 (1-2), 1-20.

Doglioni, C., S. Barba, E. Carminati and F. Riguzzi (2011). Role of the brittle-ductile transition on fault activation, Phys. Earth Planet. Inter., 184, 160-171.

Doglioni, C., S. Barba, E. Carminati and F. Riguzzi (2012). Strain rate gradient as an indicator of seismic loading triggered by the brittle-ductile transition and fluids response; submitted to GSA Bulletin.

Dolan, J.F., and J. Avouac (2007). Active fault-related folding; structural evolution, geomorphologic expression, paleoseismology, and seismic hazards, Journal of Geophysical Research, 112 (B3).

ENEL-DCO (1984). Rapporto per la localizzazione di un impianto nucleare nella Regione Lombardia, ENELDCO-USA, Roma, 33 volumes, unpublished.

Erslev, E.A. (1991). Trishear fault-propagation folding, Geology, 19, 617-620.

Eva, E., G. Ferretti and S. Solarino (2005). Superposition of different stress orientations in the western sector of the northern Apennines (Italy), J Seismol., 9, 413-430.

Falletti, P., R. Gelati and S. Rogledi (1995). OligoceneMiocene evolution of the Monferrato-Langhe, related to deep structures, In: R. Polino and R. Sacchi (eds.), Rapporti Alpi-Appennino, Accad. Naz. Scienze, 14, 1-20.

Fantoni, R., R. Bersezio and F. Forcella (2004). Alpine structure and deformation chronology at the Southern AlpsPo Plain border in Lombardy, Bollettino della Società Geologica Italiana, 123, 463-476.

Festa, A., P. Boano, A. Irace, S. Lucchesi, M.G. Forno, F. Dela Pierre, G. Fioraso and F. Piana (2009a). Carta Geologica d'Italia alla scala 1:50.000, Foglio 156 "Torino Est", ISPRA - Istituto Superiore per la Protezione e la Ricerca Ambientale, Roma.

Festa, A., F. Dela Pierre, A. Irace, F. Piana, G. Fioraso, S. Lucchesi, P. Boano and M.G. Forno (2009b). Note illustrative della Carta Geologica d'Italia alla scala 1:50.000, Foglio 156 "Torino Est", ISPRA - Istituto Superiore per la Protezione e la Ricerca Ambientale, Roma, 143 pp.

Forno, M.G. (1982). Studio Geologico dell'altopiano di Poirino (Torino), Geogr. Fis e Dinam. Quat., 5, 129-162.

Frepoli, A., and A. Amato (1997). Contemporaneous extension and compression in the Northern Apennines from earthquake fault plane solutions, Geophys J. Int., 129, 368388.

Gaetani, M., and F. Jadoul (1987). Controllo ancestrale sui principali lineamenti strutturali delle Prealpi lombarde centrali, Rendiconti della Società Geologica Italiana, 10, 21-24.

Galadini, F., M.E. Poli and A. Zanferrari (2005). Seismogenic sources potentially responsible for earthquakes with $M>$ 6 in the Eastern Southern Alps (Thiene-Udine sector, NE Italy), Geophysical Journal International, 160, 1-24.
Galadini, F., P. Galli, A. Cittadini and B. Giaccio (2001a). Late Quaternary fault movements in the Mt. Baldo-Lessini Mts. sector of the Southalpine area (northern Italy), Geologie en Mijnbouw (Netherlands Journal of Geosciences), 80, 119-140.

Galadini, F., P. Galli, D. Molin and G. Ciurletti (2001b). Searching for the source of the 1117 earthquake in Northern Italy: a multidisciplinary approach, In: T. Glade et al. (eds.), The use of historical data in natural hazard assessments, Kluwer Academic Publisher, 3-27.

Gasparini, C., G. Iannaccone and R. Scarpa (1985). Fault plane solutions for the Italian peninsula, Tectonophysics, 117, 59-78.

Giardina, F., A.M. Michetti, L. Serva and C. Doglioni (2004). The seismic potential of the Insubria Region (Southern Alps): insights from topographic and rheological modelling, Bollettino di Geofisica Teorica e Applicata, 45, 86-91.

Giardina, F. (2006). Dinamica superficiale e dinamica crostale durante il Quaternario lungo la fascia prealpina lombarda, $\mathrm{PhD}$ Thesis, Università dell'Insubria, 157 pp.

Giglia, G., G. Capponi, L. Crispini and M. Piazza (1996). Dynamics and seismotectonics of the West-Alpine arc, Tectonophysics, 267, 143-175.

Giraudi, C. (1981). Presenza di depositi medio-pleistocenici intensamente deformati in Val Cerrina (Monferrato settentrionale), Geogr. Fis. Din. Quat., 4, 69-74.

Gruppo di Studio del Quaternario Padano (1976). Studio interdisciplinare del "Rilievo Isolato" di Trino (Bassa Pianura Vercellese, Piemonte), Quaderno n.3, Litografia Massaza and Sinchetto, Torino.

Guidoboni, E. (1986). The earthquake of December 25, 1222: analysis of a myth, Geologia Applicata e Idrogeologia, 21, 413-424.

Guidoboni, E. (2002). Historical Seismology: the Long Memory of the Inhabited World, In: W.H.K. Lee, H. Kanamori, P.C. Jennings and C. Kisslinger (eds.), International Handbook of Earthquake and Engineering Seismology, Part A, Academic Press for IASPEI, London-San Diego, 775-790.

Guidoboni, E., and A. Comastri (2005). Catalogue of earthquakes and tsunamis in the Mediterrean area from the 11 th to the 15 th century, vol. 2, Bologna, INGV and SGA Storia Geofisica Ambiente srl., 950 pp.

Guidoboni, E., A. Comastri and E. Boschi (2005). The "exceptional" earthquake of 3 January 1117 in the Verona area (Northern Italy): A critical time review and detection of two lost earthquakes (lower Germany and Tuscany), Journal of Geophysical Research, B12309.

Guidoboni, E., G. Ferrari, D. Mariotti, , A. Comastri, G. Tarabusi and G. Valensise (2007). CFTI4Med, Catalogue of Strong Earthquakes in Italy (461 B.C.-1997) and Mediterranean Area (760 B.C.-1500), INGV- SGA; available at http: / / storing.ingv.it/ cfti4med/

Guzofski, C.A., J.H. Shaw, G. Lin and P.M. Shearer (2007). 
Seismically active wedge structure beneath the Coalinga anticline, San Joaquin basin, California, J. Geophys. Res., 112, B03S05.

Hardy, S., and M. Ford (1997). Numerical modeling of trishear fault propagation folding, Tectonics, 16, 841-854.

HERP - Headquaters for Earthquake Research Promotion (2009). Long-term assessment on seismic activity along Japan trench offshore Sanriku and offshore Boso Peninsular; http: / / www.jishin.go.jp/main/chousa / 09mar_sanriku / index.htm [in Japanese with many figures].

INGV (2000). DOM4.1, un database di osservazioni macrosismiche di terremoti di area italiana al di sopra della soglia del danno; available at http: / / emidius.mi.ingv.it/ $\mathrm{DOM} /$

INGV (2004). Terremoto del 24 novembre 2004 ore 22:59 UTC - Risentimento macrosismico preliminare; available at http:/ / legacy.ingv.it/ roma/attivita/pererischio/ macro sismica/macros / campi/ effettirecenti/salo241104.gif

INGV (2012). Terremoto in Pianura Padana-Emiliana - 29 maggio $2012 \mathrm{M}_{\mathrm{L}}$ 5.8; available at http: / terremoti.ingv.it/ images/ultimi-eventi/2012/comunicato_2_ingv_29mag gio.pdf

Irace, A., P. Clemente, M. Natalicchio, L. Ossella, S. Trenkwalder, D.A. De Luca, P. Mosca, F. Piana, R. Polino and D. Violanti (2009). Geologia e Idrostratigrafia Profonda della Pianura Padana Occidentale, Regione Piemonte, 111 pp., 61 tables; Firenze La Nuova Lito, 2009, ISBN 978-88-904554-0-7; available online at http: / / www. regione.piemonte.it/ acqua/idrostrat.htm

Ishiyama, T., K. Mueller, M. Togo, A. Okada and K. Takemura (2004). Geomorphology, kinematic history, and earthquake behaviour of the active Kuwana wedge thrust anticline, central Japan, J. Geophys. Res., 109, B12408.

ITHACA (2000). ITHACA Italy Hazard from Capable Faults: a database of active faults of the Italian onshore territory, A.M. Michetti, L. Serva and E. Vittori (eds.), CD-ROM and explication notes, ANPA; the updated version of the database is available online at http: / / www.isprambiente. gov.it/site/en-GB/Projects/ITaly_HAzards_from_CApable _faulting/default.html

Jackson, J., J.F. Ritz, L. Siame, and G. Raisbeck (2002). Fault growth and landscape development rates in Otago, New Zealand, using in situ cosmogenic 10Be, Earth and Planetary Science Letters, 195, 185-193.

Jia, D., Y. Li, A. Lin, M. Wang, W. Chen, X. Wu, Z. Ren, Y. Zhao and L. Luo (2010). Structural model of $2008 \mathrm{Mw}$ 7.9 Wenchuan earthquake in the rejuvenated Longmen Shan thrust belt, China, Tectonophysics, 491, 174-184 .

Johnson, K.M., and A.M. Johnson (2002). Mechanical models of trishear-like folds, Journal of Structural Geology, 24, 277-287.

Livio, F., A.M. Michetti, G. Sileo, C. Carcano, K. Mueller, S. Rogledi, L. Serva, E. Vittori and A. Berlusconi (2009a).
Quaternary capable folds and seismic hazard in Lombardia (Northern Italy): the Castenedolo structure near Brescia, Boll. Soc. Geol. It., 128 (1), 191-200.

Livio, F., A. Berlusconi, A.M. Michetti, G. Sileo, A. Zerboni, L. Trombino, M. Cremaschi, K. Mueller, E. Vittori, C. Carcano and S. Rogledi (2009b). Active fault-related folding in the epicentral area of the December 25, $1222\left(\mathrm{I}_{\mathrm{O}}=\right.$ IX MCS) Brescia earthquake (Northern Italy): seismotectonic implications, Tectonophysics, 476 (1-2), 320-335.

Livio, F., A. Berlusconi, K. Chunga, A.M. Michetti and G. Sileo (2011). New stratigraphic and structural evidence for Late Pleistocene surface faulting along the Monte Olimpino Backthrust (Lombardia, N Italy), Rend. Online Soc. Geol. It., 14, 17-25; doi:10.3301/ROL.2011.03.

Magri, G., and D. Molin (1986). I Terremoti del 3 Gennaio 1117 e del 25 Dicembre 1222, ENEA-RTI PAS-ISPGEOLLO, 2.

Marchetti, M. (2002). Enviromental changes in the Central Po Plain (Northern Italy) due to fluvial modifications and anthropogenic activities, Geomorphology, 44, 361-373.

McCalpin, J.P., ed. (1996). Paleoseismology, Academic Press, London, $583 \mathrm{pp}$.

Meletti, C., F. Galadini, G. Valensise, M. Stucchi, R. Basili, S. Barba, G. Vannucci and E. Boschi (2008). The ZS9 seismic source model for the seismic hazard assessment of the Italian territory, Tectonophysics, 450 (1), 85-108.

Michetti, A.M., and P.L. Hancock (1997). Paleoseismology: understanding past earthquakes using Quaternary geology, Journal of Geodynamics, 24 (1-4), 3-10.

Michetti, A.M., F. Audemard and S. Marco (2005a). Future trends in paleoseismology: Integrated study of the seismic landscape as a vital tool in seismic hazard analyses, Tectonophysics, 408, 3-21.

Michetti, A.M., F. Livio, K.M. Chunga, E. Esposito, D. Fanetti, R. Gambillara, S. Martin, F. Pasquarè, G. Sileo and E. Vittori (2005b). Ground effects of the $M_{L}$ 5.2, November 24th, 2004, Salò earthquake, Northern Italy and the seismic hazard of the Western Southern Alps, Rendiconti della Società Geologica Italiana, 1, 134-135.

Michetti, A.M., E. Esposito, L. Guerrieri, S. Porfido, L. Serva, R. Tatevossian, E. Vittori, F. Audemard, T. Azuma, J. Clague, V. Comerci, A. Gürpinar, McCalpin, B. Mohammadioun, J. Mohammadioun, N.A. Mörner, Y. Ota and E. Roghozin (2007). Environmental Seismic Intensity Scale - ESI 2007. Memorie Descrittive della Carta Geologica d'Italia, 74, 7-54, Servizio Geologico d'Italia - Dipartimento Difesa del Suolo, APAT, Roma, Italy.

Montone, P., T.M. Mariucci, S. Pondrelli and A. Amato (2004). An improved stress map for Italy and surrounding regions (central Mediterranean), Journal of Geophysical Research, 109, B10410; doi:10.1029/2003JB002703.

Mosca, P. (2006). Neogene basin evolution in the Northern Po Plain (NW Italy). Insights from seismic interpretation, 
subsidence analysis and low temperature (U-Th)/He thermocronology, PhD Thesis, VU University Amsterdam, 190 pp.

Mosca, P., R. Polino, S. Rogledi and M. Rossi (2009). New data for the kinematic interpretation of the Alps-Apennines junction (Northwestern Italy), Int. J. Earth. Sci.; doi: 10.1007/s00531-009-0428-2.

Muttoni, G., C. Carcano, E. Garzanti, M. Ghielmi, A. Piccin, R. Pini, S. Rogledi and D. Schiunnach (2003). Onset of major Pleistocene glaciations in the Alps, Geology, 31 (11), 989-992.

Nardon, S., D. Marzorati, A. Bernasconi, S. Cornini, M. Gonfalini, S. Mosconi, A. Romano and T. Terdich (1990). Cavone oil field (Italy): an example of the application of integrated methodologies to reservoir characterization, Mem. Soc. Geol. It., 45, 791-805.

Ori, G., M. Roveri and F. Vannoni (1986). Plio-Pleistocene sedimentation in the Apenninic-Adriatic foredeep (Central Adriatic Sea, Italy), Spec. Publ. Int. Ass. Sediment, 8, 183-198.

Orombelli, G. (1976). Indizi di deformazioni tettoniche quaternarie al margine meridionale delle Prealpi Comasche, Quaderni del Gruppo di Studio del Quaternario Padano, 3, 25-37.

Orombelli, G. (1979). Il Ceppo dell'Adda: revisione stratigrafica, Riv. Ital. Paleont., 85 (2), 1-64.

Pellegrini, M., and L. Vezzani (1978). Faglie attive in superficie nella pianura padana presso Correggio (Reggio Emilia) e Massa Finalese (Modena), Geogr. Fis. Dinam. Quat, 1, 141-149.

Peresan, A., E. Zuccolo F. Vaccari and G.F. Panza (2009). Neodeterministic seismic hazard scenarios for NorthEastern Italy, Ital.J.Geosci. (Boll.Soc.Geol.It.), 128, 229238.

Pessina, V., G. Franceschina, P. Vannoli, L. Luzi and F. Pacor (2006). Damage distribution and seismological model of the November 2004, Salò (Northern Italy) earthquake, Proceedings of the First European Conference on Earthquake Engineering and Seismology (September 3-8, 2006, Geneva, Switzerland), Paper n. 1371, 10 pp.

Petrucci, F., and S. Tagliavini (1969). Note Illustrative della Carta Geologica d'Italia, Foglio 61, Cremona, Servizio Geologico d'Italia, 43 pp.

Piana, F., and R. Polino (1994). La zona trasgressiva di Rio Freddo e l'evoluzione convergente del Monferrato e della Collina di Torino, Atti Tic. Sc. Ter. (serie speciale), 1, 167180.

Piana, F., and R. Polino (1995). Tertiary structural relationships between Alps and Apennines: the critical Torino hill and Monferrato area, Northwestern Italy, Terra Nova, 7 , 138-143.

Picotti, V., and F.J. Pazzaglia (2008). A new active tectonic model for the construction of the Northern Apennines mountain front near Bologna (Italy), Journal of Geophysical Research, 113, B08412; doi:10.1029/2007/JB005307.

Pieri, M., and G. Groppi (1981). Subsurface geological structure of the Po plain, Italy, Progetto Finalizzato Geodinamica-Agip n. 414.

Poli, M.E., P. Burrato, F. Galadini and A. Zanferrari (2008). Seismogenic sources responsible for destructive earthquakes in NE Italy, Bollettino di Geofisica Teorica e Applicata, 49 (3-4), 1-13.

Porfido, S., E. Esposito, E. Vittori, G. Tranfaglia, A.M. Michetti, A.M. Blumetti, L. Ferreli, L. Guerrieri and L. Serva (2002). Areal distribution of ground effects induced by strong earthquakes in the southern Apennines (Italy), Surveys in Geophysics, 23, 529-562.

Postpischl, D., ed. (1985). Catalogo dei Terremoti Italiani dall'Anno 1000 al 1980, CNR, Quaderni "La Ricerca Scientifica", 114 (2B), 239 pp.

Ravaglia, A., S. Seno, G. Toscani and R. Fantoni (2006). Mesozoic extension controlling the Southern Alps thrust front geometry under the Po Plain, Italy: Insights from sandbox models, Journal of Structural Geology, 28, 2084-2096.

Regione Emilia Romagna and ENI-AGIP (1998). Riserve idriche sotterranee della Regione Emilia-Romagna, edited by G. Di Dio, Florence, S.EL.CA., 120 pp.

Riguzzi, F., M. Crespi, R. Devoti, C. Doglioni, G. Pietrantonio and A.R. Pisani (2012). Geodetic strain rate and earthquake size: new clues for seismic hazard studies, Physics of the Earth and Planetary Interiors, 206-207, 67-75.

Satake, K., Y. Namegaya and S. Yamaki (2008). Numerical simulation of the AD 869 Jogan tsunami in Ishinomaki and Sendai plains, Annual Report on Active Fault and Paleoearthquake Researches, 8, 71-89.

Sauro, U., and D. Zampieri (2001). Evidence of recent surface faulting and surface rupture in the Fore-Alps of Veneto and Trentino (NE Italy), Geomorphology, 40 (34), 169-184.

Sawai, Y., M. Shishikura, Y. Okamura, K. Takada, T. Matsu'ura, T.T. Aung, J. Komatsubara, Y. Fujii, O. Fujiwara, K. Satake, T. Kamataki and N. Sato (2007). A study on paleotsunami using handy geoslicer in Sendai Plain (Sendai, Natori, Iwanuma, Watari, and Yamamoto), Miyagi, Japan, Annual Report on Active Fault and Paleoearthquake Researches, 7, 47-80.

Scardia, G., G. Muttoni and D. Sciunnach (2006). Subsurface magnetostratigraphy in the Po Plain (Italy): temporal constraints on onset of the Ice Ages, erosion, and uplift in the Southern Alps, Geological Society of America Bulletin, 118 (11), 1299-1312.

Sciunnach, D., and F. Tremolada (2004). The Lombardian Gonfolite Group in central Brianza (Como and Milano Provinces, Italy): Calcareous nannofossil biostratigraphy and sedimentary record of neo-alpine tectonics, Ecl. Geol. Helv., 97 (1), 119-131. 
Scrocca, D., E. Carminati, C. Doglioni and D. Marcantoni (2007). Slab retreat and active shortening along the central-Northern Apennines, In: O. Lacombe, J. Lavè, F. Roure and L. Verges (eds.), "Thrust belts and foreland basins: From fold kinematics to hydrocarbon systems", Frontiers in Earth Sciences, 471-487.

Selvaggi, G., F. Ferulano, M. Di Bona, A. Frepoli, R. Azzara, A. Basili, C. Chiarabba, M.G. Ciaccio, F. Di Luccio, F.P. Lucente, L. Margheriti and C. Nostro (2001). The Mw 5.4 Reggio Emilia 1996 earthquake: active compressional tectonics in the Po Plain, Italy, Geophysical Journal International, 144, 1-13.

Serpelloni, E., M. Anzidei, P. Baldi, G. Casula and A. Galvani (2005). Crustal velocity and strain-rate fields in Italy and surrounding regions; new results from the analysis of permanent and non-permanent GPS networks, Geophysical Journal International, 161 (3), 861-880.

Serva, L. (1990). Il ruolo delle scienze della terra nelle analisi di sicurezza di un sito per alcune tipologie di impianti industriali; il terremoto di riferimento per il sito di Viadana (MN), Bollettino Società. Geologica Italiana, 109 (2), 375-411.

Serva, L., and D.B. Slemmons (1995). Perspective in paleoseismology, A.E.G. Special Publication, 6, 138 pp., Seattle/Washington, Peanut Butter Publishing.

Serva, L. (1996). Criteri geologici per la valutazione della sismicità: considerazioni e proposte, In: Atti dei Convegni Lincei, 122, "Terremoti in Italia", (December 1-2, 1994, Roma, Accademia Nazionale dei Lincei), 103-116.

Servizio Geologico d'Italia. Carta Geologica d'Italia scala 1:50000, Foglio 96, Seregno, in press.

Sileo, G., F. Giardina, A.M. Michetti, K. Mueller, E. Vittori and F. Livio (2007). The active tectonics of the Insubria Region (Lombardia, NW Italy, and Ticino, SE Switzerland): preliminary remarks, Bollettino Società. Geologica Italiana, 126 (2), 411-425.

Slejko, D., F. Carraro, G.B. Carulli, D. Castaldini, A. Cavallin, C. Doglioni, R. Nicolich, G. Rebez, E. Semenza and A. Zanferrari (1987). Modello sismotettonico dell'Italia nordorientale, CNR, Rendiconto, 1, 1-82.

Slemmons, D.B., and C.M. DePolo (1986). Evaluation of active faulting and associated hazard, In: R.E. Wallace, Active Tectonics, Washington, D.C., National Academic Press.

Stucchi, M., ed. (2004). Redazione della mappa di pericolosità sismica prevista dall'ordinanza PCM 3274 del 20 Marzo 2003, Rapporto conclusivo per il Dipartimento della Protezione Civile, Gruppo di Lavoro INGV, Milano/Roma, Aprile 2004, 65 pp. +5 appendices.

Toscani, G., S. Seno, R. Fantoni and S. Rogledi (2006). Geometry and timing of deformation inside a structural arc: the case of the western Emilian folds (Northern Apennine front, Italy), Bollettino della Società Geologica Italiana,
$125(1), 59-65$.

Toscani, G., P. Burrato, D. Di Bucci, S. Seno and G. Valensise (2009). Plio-Quaternary tectonic evolution of the northern Apennines thrust fronts (Bologna-Ferrara section, Italy): seismotectonic implications, Italian Journal of Geosciences (Bollettino della Società Geologica Italiana), 128, 650-613.

Vezzoli, G., M.G. Forno, S. Andò, K. Hron, P. Cadoppi, E. Rossello and V. Tranchero (2010). Tracing the drainage change in the Po basin from provenance of Quaternary sediments (Collina di Torino, Italy), Quaternary International, 222, 64-71.

Viganò, A., G. Bressan, G. Ranalli and S. Martin (2008). Focal mechanism inversion in the Giudicarie-Lessini seismotectonic region (Southern Alps, Italy): Insights on tectonic stress and strain, Tectonophysics, 460, 106-115.

Weber, J., M. Vrabec, P. Pavlovčič-Prešeren, T. Dixon, Y. Jiang and B. Stopar (2010). GPS-derived motion of the Adriatic microplate from Istria Peninsula and Po Plain sites, and geodynamic implications, Tectonophysics, 483, 213-222.

Wells, D.L., and K.J. Coppersmith (1994). New empirical relationships among magnitude, rupture length, rupture width, and surface displacement, Bull. Seism. Soc. Am., 84, 974-1002.

Winterer, E.L., and A. Bosellini (1981). Subsidence and sedimentation on Jurassic passive continental margin Southern Alps, Italy, The American Association of Petroleum Geologists Bullettin, 65, 394-421.

Yeats, R.S. (1986). Active faults related to folding, In: R.E. Wallace, Active Tectonics, Washington, National Academy Press, 63-79.

Yeats, R.S., K. Sieh and C.R. Allen (1997). The Geology of Earthquakes, New York, Oxford University Press, 568 pp.

Zanchi, A., A. Bini, M. Felber, I. Rigamonti, and A. Uggeri (1997). Neotectonic evidences along the Lombardian foothills of the Southern Alps, Geologia Insubrica, 2, 99112.

Zehnder, A.T., and R.W. Allmendinger (2000). Velocity field for the trishear model, Journal of Structural Geology, 22, 1009-1014.

\footnotetext{
${ }^{\star}$ Corresponding author: Alessandro M. Michetti, Università dell'Insubria, Dipartimento di Scienza e Alta Tecnologia, Como, Italy; email: alessandro.michetti@uninsubria.it.

(C) 2012 by the Istituto Nazionale di Geofisica e Vulcanologia. All rights reserved.
} 